\title{
Linking white and grey matter in schizophrenia: oligodendrocyte and neuron pathology in the prefrontal cortex
}

\author{
Malin Höistad' ', Devorah Segal', Nagahide Takahashi' ${ }^{2}$ Takeshi Sakurai' ${ }^{2}$, Joseph D. Buxbaum² and \\ Patrick R. Hof ${ }^{1 *}$
}

' Department of Neuroscience, Mount Sinai School of Medicine, New York, NY, USA

2 Department of Psychiatry, Mount Sinai School of Medicine, New York, NY, USA

Edited by:

Kathleen S. Rockland, RIKEN Brain

Science Institute, Wakō, Japan

Reviewed by:

Andrew Dwork, Columbia University Medical Center, New York, NY, USA

Alan Peters, Boston University School

of Medicine, Boston, MA, USA

Kathleen S. Rockland, RIKEN Brain

Science Institute, Wakō, Japan

\section{*Correspondence:}

Patrick R. Hof, Department of

Neuroscience, Mount Sinai School of Medicine, Box 1065, One Gustave L.

Levy Place, New York, NY 10029, USA.

e-mail:patrick.hof@mssm.edu
Neuronal circuitry relies to a large extent on the presence of functional myelin produced in the brain by oligodendrocytes. Schizophrenia has been proposed to arise partly from altered brain connectivity. Brain imaging and neuropathologic studies have revealed changes in white matter and reduction in myelin content in patients with schizophrenia. In particular, alterations in the directionality and alignment of axons have been documented in schizophrenia. Moreover, the expression levels of several myelin-related genes are decreased in postmortem brains obtained from patients with schizophrenia. These findings have led to the formulation of the oligodendrocyte/myelin dysfunction hypothesis of schizophrenia. In this review, we present a brief overview of the neuropathologic findings obtained on white matter and oligodendrocyte status observed in schizophrenia patients, and relate these changes to the processes of brain maturation and myelination. We also review recent data on oligodendrocyte/myelin genes, and present some recent mouse models of myelin deficiencies. The use of transgenic and mutant animal models offers a unique opportunity to analyze oligodendrocyte and neuronal changes that may have a clinical impact. Lastly, we present some recent morphological findings supporting possible causal involvement of white and grey matter abnormalities, in the aim of determining the morphologic characteristics of the circuits whose alteration leads to the cortical dysfunction that possibly underlies the pathogenesis of schizophrenia.

Keywords: myelin, myelin-related genes, development, anterior cingulate cortex, cingulum bundle

\section{WHITE MATTER AND COGNITIVE FUNCTION}

The role of white matter in neural circuit integrity may be appreciated in terms of supporting neural functioning. Most neurons in the brain necessitate adequate myelination of their axons in order to maintain functional processing at all levels of neural systems, from autonomic processes and sensorimotor integration, to mood and thought. The importance of myelination for cognitive functioning becomes apparent in diseases that are known to be caused or affected by deficiencies in myelin, where patients show deficits in intellectual, social and emotional functioning (Dwork et al., 2007; Schmahmann et al., 2008). Leukodystrophies and leukoencephalopathies, diseases characterized by progressive degeneration of the white matter, if diagnosed in late adolescence or early adulthood can present with psychotic symptoms sometimes indistinguishable from those of schizophrenia (Davis et al., 2003; Denier et al., 2007; Walterfang et al., 2005). Likewise, patients with multiple sclerosis who display cognitive and psychiatric symptoms frequently have white matter lesions in the frontal and temporal lobes, which are the brain regions most implicated in schizophrenia (Davis et al., 2003).

Schizophrenia is a severe psychiatric illness that affects close to $1 \%$ of the population worldwide. The diagnosis is generally established at first onset of the symptoms, which occurs in most cases in early adulthood. The disease is characterized by a number of mental abnormalities that result in a distortion of perception and expression of reality. There are prominent sensory symptoms, most frequently taking the form of auditory and visual hallucinations, although such sensations can affect any sensory modality. In addition to hallucinations, the patients may experience paranoid delusions, present with disorganized thoughts and speech, and a variable degree of social and occupational dysfunction. There is a considerable degree of inheritability of the disease and prenatal causes, such as insult to the brain during embryonic development, have also been considered to play a key role in the expression of the disease at a later time (see Fallon et al., 2003).

Schizophrenia has been shown to exhibit myelin deficiencies and changes in white matter volume in the brain (Davis et al., 2003; Dwork et al., 2007; Karoutzou et al., 2008; Segal et al., 2007b; Sokolov, 2007; Walterfang et al., 2006). The myelin hypothesis in schizophrenia was first presented by Hakak et al. (2001) after their pivotal finding of altered expression of myelin-related genes in human postmortem tissue (Hakak et al., 2001). Myelin-related gene expression levels have matched the observations made on white matter abnormalities by diffusion tensor imaging (DTI), and were later confirmed in several other studies. Since the first suggestions of a myelin-related pathophysiology underlying schizophrenia, there have been numerous and extensive reports and reviews on the myelin hypothesis (Davis et al., 2003; Dwork et al., 2007; Karoutzou et al., 2008; Segal et al., 2007b; Sokolov, 2007; Walterfang et al., 2006).

Substantial deficits in myelination occur in schizophrenia, which is interesting to consider in light of previous hypotheses that the disease results from abnormal brain development (Lewis and Levitt, 
2002; Rapoport et al., 2005; Weinberger, 1986, 1987) and altered neuronal circuitry (Selemon and Goldman-Rakic, 1999), particularly in the prefrontal cortex (PFC). Neuropathologic findings in both white matter and grey matter suggest that myelin alterations in the anterior cingulate cortex (ACC) may underlie some of the behavioral deficits related to prefrontal dysfunction. We discuss some of the white matter findings and relate these to grey matter pathologies in schizophrenia, elucidating a possible impact that white matter abnormalities have on neuronal morphology and function.

\section{IMAGING AND NEUROPATHOLOGIC FINDINGS IN SCHIZOPHRENIA \\ IMAGING STUDIES}

Fractional anisotropy (FA), a measure of the directionality of water movement within the spaces in-between axons, provides an indication of white matter tract directionality and, by measuring the strength of the direction vector of water diffusion, possibly of tract integrity or coherence. A major advantage of this approach is that it can be used to study changes in schizophrenia in vivo, allowing investigation of different stages of the disease. In vivo DTI studies have revealed decreased FA in several major white matter tracts in schizophrenia (Buchsbaum et al., 1998, 2006; Kubicki et al., 2007; Lim et al., 1999; Shergill et al., 2007), including the cingulum (Kubicki et al., 2003; Wang et al., 2004). In addition, positron emission tomography (PET) imaging has demonstrated increased relative metabolic rates in white matter in schizophrenia, which may represent white matter inefficiency or defects resulting in increased metabolic needs (Buchsbaum et al., 2007), in contrast to findings in the grey matter which have shown decreases in regional cerebral blood flow in the ACC (Tamminga et al., 1992).

Although previous DTI studies have shown decreases in FA in the cingulum bundle as well as in the overlying cingulate gyrus in patients with schizophrenia (Fujiwara et al., 2007; Kubicki et al., 2003; Kumra et al., 2005; Sun et al., 2003; Wang et al., 2004; White et al., 2008), the findings have been somewhat inconsistent, due in large part to small subject samples and different methods of identifying particular brain regions of interest (Kubicki et al., 2007). Segal and collaborators recently investigated the volume and FA in the cingulate gyrus in a large group of subjects with chronic schizophrenia along with a group of patients with recent-onset schizophrenia and healthy control subjects matched for age and sex (Segal, 2008; Segal et al., 2007a). The anterior cingulate gyrus was traced and segmented into axial portions allowing detection of localized changes. Volume was calculated for the anterior cingulate gyrus, and average FA values were calculated for each segment looking separately at grey and white matter. A significant decrease in the overall grey matter volume was found in the anterior cingulate gyrus in persons with schizophrenia. In both grey and white matter, persons with recent-onset schizophrenia had the highest FA in several regions, and persons with chronic schizophrenia had the lowest (Figure 1). These results demonstrate both white and grey matter abnormalities in the cingulate gyrus in schizophrenia (Segal, 2008), which may reflect abnormalities in neuron spacing or columnar organization.

MRI studies of the grey matter have revealed regionally reduced cortical volumes in schizophrenia (Honea et al., 2005, 2008; Nesvag et al., 2008; Okugawa et al., 2007), including the ACC (Baiano et al., 2007; Wang et al., 2007). Magnetic transfer imaging (MTI)

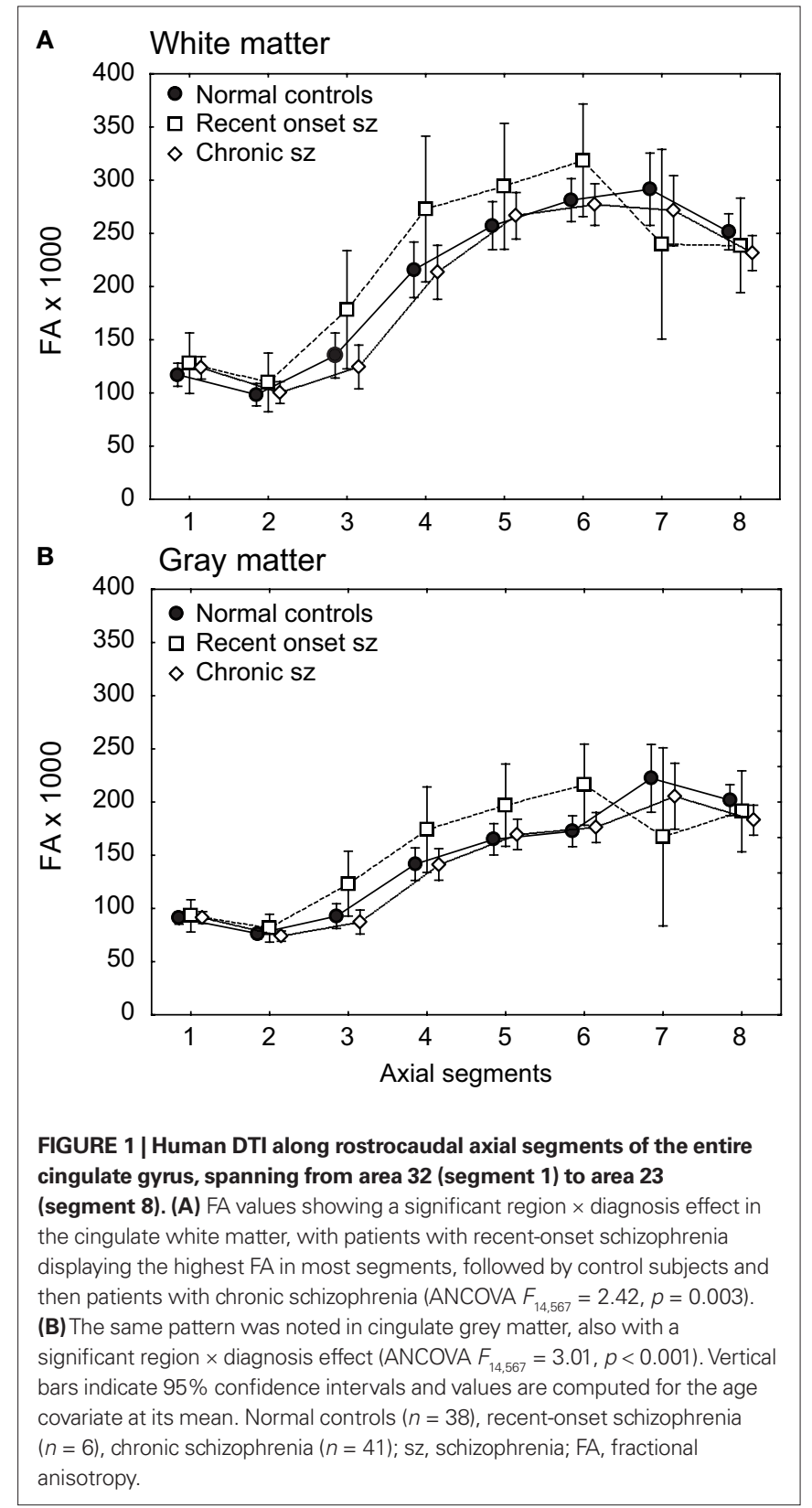

assessment of macromolecular structural integrity enables separate analysis of white and grey matter, which may help to elucidate early neuropathological changes. Foong et al. (2001) found MTI changes in the grey matter of frontal and temporal areas, while white matter abnormalities were observed only in temporal areas.

\section{OLIGODENDROCYTE AND MYELIN STUDIES}

In attempts to localize and identify a cellular correlate of the white matter changes observed by brain imaging in vivo, oligodendrocytes have come to be an important focus of investigation. Analyses of the number, densities and distribution patterns of oligodendrocytes can be performed in both the white and grey matter. Stark et al. (2004) found decreased oligodendrocyte densities in cingulate area 24 but not in the adjacent paracingulate area 32, and Hof et al. (2003) found 
decreased densities of oligodendrocytes in the prefrontal area 9 of the superior frontal gyrus in subjects with schizophrenia. In contrast, in a subsequent study, Hof and coworkers evaluated the degree of oligodendrocyte clustering in the anterior cingulum bundle, but found no differences using postmortem tissue from chronic schizophrenics versus age-matched controls (Segal et al., 2009). These results suggest that more subtle oligodendrocyte or myelin anomalies may underlie the structural deficits observed by brain imaging in the cingulum bundle in schizophrenia. On the ultrastructural level, electron microscopy studies of oligodendrocytes in the PFC have demonstrated apoptotic oligodendrocytes, irregularities of mitochondria in oligodendrocytes and damaged myelin in area 10 in schizophrenic brains (Uranova et al., 2001, 2004).

\section{GREY MATTER AND NEURON STUDIES}

Postmortem studies, assessing the gyrification index, have found reductions in cortical folding in schizophrenia (Kulynych et al., 1997). Studies on changes in neuronal densities in different cortical regions in schizophrenia have been conflicting, and no definite pattern of neuronal density alterations has yet been established. These differences in observation may in part be due to differences in methodological approaches and procedures and the cortical regions studied. Some postmortem studies of the ACC and dorsolateral PFC (DLPFC) have suggested a decrease in neuronal density. Benes reported a lower neuronal density (mainly in layer II) in areas 24 and 10, primarily of small interneurons (Benes et al., 1991), which suggested an alteration in intrinsic neuronal circuits (Benes, 2000). Other investigators have shown increased neuronal density in areas 9 and 46, without increased absolute numbers of neurons in patients with schizophrenia (Selemon et al., 1995, 1998). This implied that cortical volume in select cortical regions is reduced in schizophrenia, possibly because of reduced neuropil. Goldman-Rakic and coworkers proposed that an altered brain connectivity plays a critical role in the development of schizophrenia (Selemon and Goldman-Rakic, 1999). In other studies on subcortical regions, observations have been made of reductions in the size and total neuron numbers, but not in neuronal density, in the putamen and the amygdala (Kreczmanski et al., 2007).

Cytoarchitectural studies have analyzed neuronal arrangements in terms of interneuronal distances, or mean cell spacing (Casanova et al., 2005, 2008) showing that mean cell spacing was reduced in area 9 in schizophrenic patients, which would imply a higher neuronal density. Rajkowska and coworkers found that in area 9, there was a downward shift in neuronal sizes, accompanied by increases in the density of "small neurons" in layer II, interpreted as GABAergic interneurons, while there was a decrease in the density of "very large neurons" in layer III, presumably pyramidal neurons, in patients with schizophrenia. Concomitant morphological studies at the single neuron level have demonstrated impoverished dendritic structures of pyramidal neurons (Broadbelt et al., 2002) and loss of dendritic spines in schizophrenia (Garey et al., 1998; Glantz and Lewis, 2000; Sweet et al., 2009), as well as in non-human primate models (Selemon et al., 2007).

Another interesting finding is an anomalous distribution of the so-called interstitial white matter neurons in schizophrenia. These interstitial neurons have been suggested to be remnants of subplate neurons that normally undergo programmed cell death during brain maturation (Chun and Shatz, 1989). However, in certain species including human, these white matter interstitial neurons are to some degree normally found in healthy adults (Kostovic and Rakic, 1980). The interstitial white matter neurons have been found to be increased in prefrontal white matter (Akbarian et al., 1996; Anderson et al., 1996) and temporal white matter (Rioux et al., 2003) in subjects with schizophrenia, supporting further the presence of a neurodevelopmental abnormality in schizophrenia (Weinberger, 1986, 1987) (See Table 1 for a summary of imaging, and grey and white matter studies in schizophrenia.).

\section{THE INVOLVEMENT OF ACC IN SCHIZOPHRENIA THE CINGULATE GYRUS AND THE CINGULUM BUNDLE}

The ACC has been studied in many neuropathologic investigations of schizophrenia. From a topographical viewpoint, the ACC consist of Brodmann area 24, and includes the subgenual area 25, and according to some authors also the paracingulate prefrontal area 32. In the human, area 24 can be subdivided along its rostrocaudal and dorsoventral extent, through which it shows gradients in cytoarchitecture as well as topography in its afferent and efferent projections (Ongür et al., 2003; Palomero-Gallagher et al., 2008; Vogt et al., 1995), and area 32 extends dorsocaudally as a dorsal strip (32') overlying area 24 (Figure 2). The cingulum bundle is the major coherent white matter tract of the cingulate gyrus, radiating superiorly from the corpus callosum to the cingulate cortex. The ACC receives processed multimodal sensory information from insular, temporal, parietal association cortices, and emotional information from the amygdala and the orbitofrontal cortex (Jones and Powell, 1970). The multimodal sensory input enables the ACC to respond to stimuli with motivational significance, activating motor and visceromotor responses, including vocalizations. For details on cingulate circuitry, see Beckmann et al. (2009), Iversen (1984), Kunishio and Haber (1994), Van Hoesen et al. (1993), Vogt and Pandya (1987) and Vogt et al. (1987).

\section{THE ROLE OF ACC IN BEHAVIOR WITH IMPLICATIONS FOR SCHIZOPHRENIA}

The first observation that the ACC had a role in emotional and visceromotor behavior was from non-human primate studies. Electrical stimulation of the ACC in monkeys generates changes in blood pressure, heart rate, respiratory rate, and agitation and vocalizations (Devinsky et al., 1995; Jürgens et al., 1967; Neafsey, 1990; Smith, 1945). Primate lesion studies have shown aggressiveness, emotional blunting, and impaired infant-mother interactions, further indicating that the ACC has an important role in emotional and social functions (Devinsky et al., 1995; Glees et al., 1950; Mirsky et al., 1957). However, these early lesion studies commonly involved more than just area 24 or area 32 and often included the parts of the OFC, and later confirmation studies have shown various effects in monkeys (Devinsky et al., 1995; Hadland et al., 2003). In the human, different observations have been made from tumors, strokes, seizures and electrical stimulation studies involving the ACC, but these have been quite variable (Devinski and Luciano, 1993; Devinsky et al., 1995). For example, surgical interventions of the ACC have focused on management of pain, chronic depression and obsessive-compulsive behavior (Devinsky et al., 1995). It is likely that the social aspects of the ACC that have been observed are related to its connections with the OFC. For an overview of the 
Table 1 | Examples of neuropathological observations on the human cerebral cortex and underlying white matter in schizophrenia.

\begin{tabular}{|c|c|c|c|}
\hline Parameter & Method & Observations in schizophrenia & References \\
\hline \multicolumn{4}{|l|}{ IMAGING STUDIES } \\
\hline $\begin{array}{l}\text { White matter fractional } \\
\text { anisotropy }\end{array}$ & DTI & $\begin{array}{l}\text { Decreased FA in the cingulum bundle } \\
\text { Decreased FA in the cingulum bundle } \\
\text { Decreased FA in the cingulum bundle } \\
\text { Decreased FA in the frontal WM }\end{array}$ & $\begin{array}{l}\text { Kubicki et al. (2003) } \\
\text { Sun et al. (2003) } \\
\text { Wang et al. (2004) } \\
\text { Kumra et al. (2005) }\end{array}$ \\
\hline Myelin water fraction & MRI & Reduced myelin water fraction in frontalWM & Flynn et al. (2003) \\
\hline White matter metabolism & PET & Increased in the cingulum bundle & Buchsbaum et al. (2007) \\
\hline Gyrification index & MRI & Reduction in cortical folding in frontal regions & Kulynych et al. (1997) \\
\hline Sulcal patterning & $\mathrm{MRI}$ & Shallower sulcal depth in the parietal operculum & Csernansky et al. (2008) \\
\hline \multirow[t]{6}{*}{ Cortical volume } & \multirow[t]{6}{*}{$\mathrm{MRI}$} & Reduced volume of frontal lobes & Andreasen et al. (1986) \\
\hline & & Reduced volume of the ACC & Baiano et al. (2007) \\
\hline & & Reduced volume of the ACC & Koo et al. (2008) \\
\hline & & Cortical thinning of prefrontal and temporal cortices & Nesvag et al. (2008) \\
\hline & & Cortical thinning of ACC, temporal and parietal cortices & Narr et al. (2005) \\
\hline & & $\begin{array}{l}\text { Progressive grey matter loss starting in the parietal cortex } \\
\text { and progressing towards temporal cortex and DLPFC }\end{array}$ & Thompson et al. (2001) \\
\hline \multirow[t]{2}{*}{ Grey matter metabolism } & rCBF & Decreased rCBF in ACC & Tamminga et al. (1992) \\
\hline & PET & Decreased glucose metabolic rates in the ACC & Haznedar et al. (2004) \\
\hline $\begin{array}{l}\text { Macromolecular structure } \\
\text { integrity }\end{array}$ & MTI & Alterations in frontotemporal GM and temporal WM & Foong et al. (2000) \\
\hline
\end{tabular}

\section{OLIGODENDROCYTE AND MYELIN STUDIES}

in white matter

Oligodendrocyte density Stereology

in grey matter

Oligodendrocyte

morphology

Myelin sheaths

Gene expression of

myelin-related genes

Stereology
Stereology
EM
EM
Microarrays
association
analysis

Association analysis
Decreased density in the WM of SFG

Unaltered density in the cingulum bundle

Decreased density in area 24 but not in area 32

Decreased density in the SFG

Apoptotic oligodendrocytes in area 10

Damaged myelin in area 10

Decreased expression of myelin-associated glycoprotein (MAG), myelin and lymphocyte protein (MAL), 2',3'-cyclic nucleotide 3'-phosphodiestase (CNP), gelsolin, transferrin and HER3 (neuregulin receptor) in the DLPFC

Association of 10 single nucleotide polymorphisms from six myelin-related genes

Decreased expression of CNP in GM of anterior PFC
Hof et al. (2003)

Segal et al. (2009)

Stark et al., (2004)

Hof et al. (2003)

Uranova et al. (2001)

Uranova et al. (2001)

Hakak et al. (2001)

Jungerius et al. (2008)

Flynn et al. (2003)

Protein expression of myelin-related genes

\section{GREY MATTER AND NEURON STUDIES}

Capillary lengths Neuronal density

Interstitial white matter neurons

Neuronal distribution

Neural soma size

Neuronal integrity

Stereology

2D morphometric

analysis*

3D morphometric

analysis*

$2 \mathrm{D}$ analysis

Stereology

3D analysis*

Golgi stains
No differences in are 24 and area 9

Decreased in area 24

and area 10

Increases in area 9

and area 46

Increased neurons in prefrontal white matter

Decreased mean cell spacing in area 9

Smaller mean neuronal somas in area 9

Decreased number of dendrites in area 32

Decreased dendritic spine density in DLPFC
Kreczmanski et al. (2005)

Benes et al. (1991)

Selemon et al. (1995, 1998)

Akbarian et al. (1996) and Anderson et al. (1996)

Casanova et al. $(2005,2008)$

Rajkowska et al. (1998)

Broadbelt et al. (2002)

Glantz and Lewis (2000),

Kolluri et al. (2005) and

Sweet et al. (2009)

Glantz and Lewis (1997) and

Eastwood and Harrison (1995)

Synaptic proteins

Synaptophysin

Alterations in synaptic protein expression

latest morphological observations This table is not a comprehensive summary of all neuropathologic findings in schizophrenia. Rather, it gives exampleso
in which the myelin hypothesis may have an impact, in relation to some of the classical neuropathologic findings.

WM, white matter: GM, grey matter; ACC, anterior cingulate cortex; DLPFC, dorsolateral prefrontal cortex; SFG, superior frontal gyrus; FA, fractional anisotropy; DTI, diffusion tensor imaging; MTI, magnetic transfer imaging; MRI, magnetic resonance imaging; rCBF, regional cerebral blood flow; PET, positron emission tomography; EM, electron microscopy

*Biased to tissue orientation and limited sampling. 

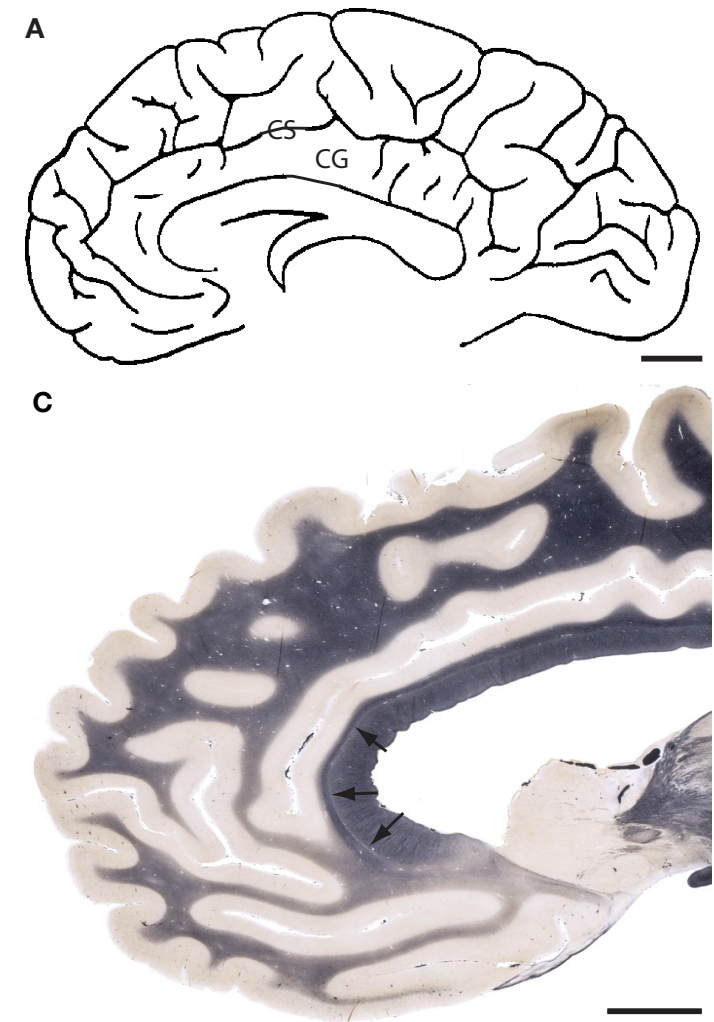

FIGURE 2 |The cingulate cortex and cingulum bundle. (A) Medial surface view of the human brain, depicting the cingulate gyrus (CG) and the cingulate sulcus (CS). (B) Human flat map of the cingulate cortex and surrounding areas. Note that the anterior cingulate is composed of the subgenual area 25, the paracingulate area 32, and six cytoarchitecturally different subregions of area 24
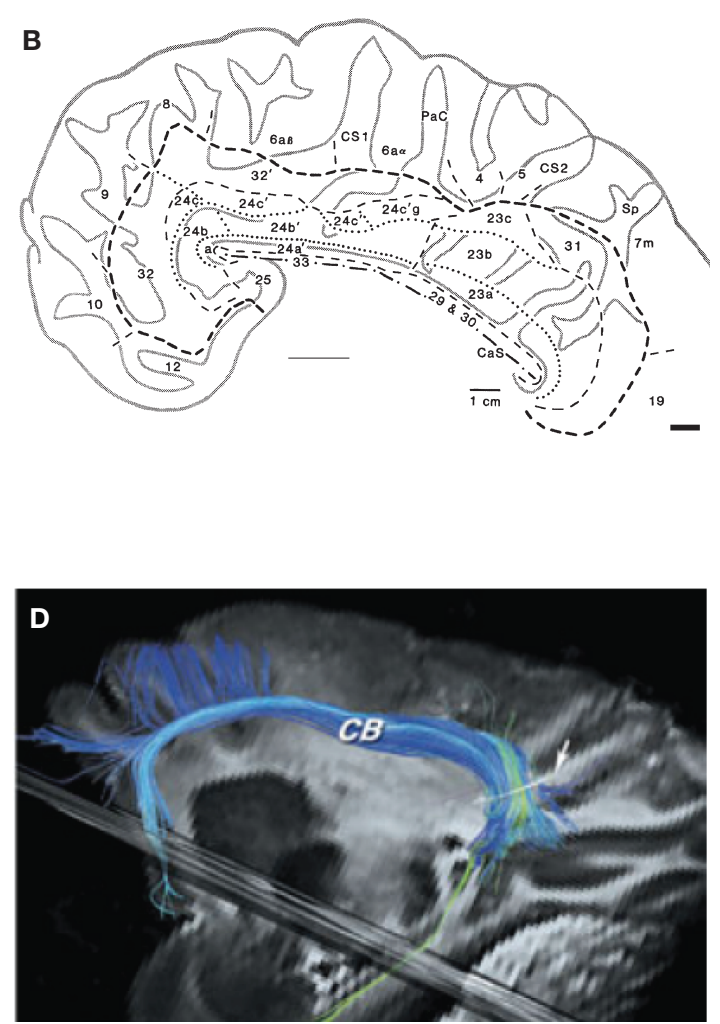

(24a,b,c, a', b', c', respectively). (C) Human sagittal myelin stain showing the cingulate cortex and the cingulum bundle (arrows) as a thin fiber tract overlying the corpus callosum. (D) The cingulum bundle in the rhesus monkey, as visualized with DTI. Panels (A,B) modified from Vogt et al. (1995), and panel (D) from Schmahmann et al. (2007), with permissions. Scale bars $1 \mathrm{~cm}$.
ACC in social function, see Amodio and Frith (2006), Bush et al. (2000), Rudebeck et al. (2008) and Rushworth et al. (2007a,b). It is noteworthy that both the sensory integration and social processing modalities are pertinent to the presumed ACC dysfunction in schizophrenia. It is however important to keep in mind that social and emotional functions are separate entities though they commonly interact.

\section{BRAIN MATURATION AND MYELINATION MYELINATION SEQUENCES}

During ontogeny, the cognitive development of children and young adults depends closely on the progressive myelination of cortical axons (Casey et al., 2005; Fuster, 2002; Gibson and Petersen, 1991; Paus, 2005). As first shown by Flechsig in 1901, and later by Yakoklev in human postmortem myelin preparations (Flechsig, 1901; Yakovlev and Lecours, 1967), the regions that are myelinated first include the spinal cord and brainstem, and then myelination continues dorsally towards the frontal cortex, with proximal pathways myelinating prior to distal pathways, sensory pathways prior to motor pathways, and downstream projection pathways prior to association pathways (Volpe, 2000) and prefrontal regions myelinating the last (Lenroot and Giedd, 2006). Although initiated prenatally in humans, most tracts and regions become myelinated during the first year of life, and myelination continues into the second and third decade of life in humans (Figure 3). These early reports have been confirmed and further refined with modern brain imaging techniques (Ballesteros et al., 1993; Knickmeyer et al., 2008; Lenroot and Giedd, 2006; Miller et al., 2003; Mukherjee and McKinstry, 2006; Mukherjee et al., 2001, 2002; Paus et al., 2001; Sowell et al., 2003; Volpe, 2000). In addition, the number of oligodendrocytes drastically increases after birth through maturity (O'Kusky and Colonnier, 1982). It is this increase in oligodendrocytes and myelination that accounts for the large increase in white matter volume observed during the first years of life (Knickmeyer et al., 2008; Lenroot and Giedd, 2006).

The PFC is the last region of the brain to mature (Fuster, 2002). The volume of prefrontal white matter increases through childhood and early adolescence, and is not complete until early adulthood (Paus et al., 2001). As such, myelination per se can be used as an index of cortical maturation (Fuster, 2002). In the human cingulum bundle, the onset of myelination is around gestational week 38 and is fully myelinated at 1 year of age in humans (Gilles et al., 1983). It should be kept in mind however that when adulthood is reached, the cortical areas 24, 25 and 32 are poorly myelinated (Ongür et al., 2003), although the underlying cingulum bundle is highly myelinated. 


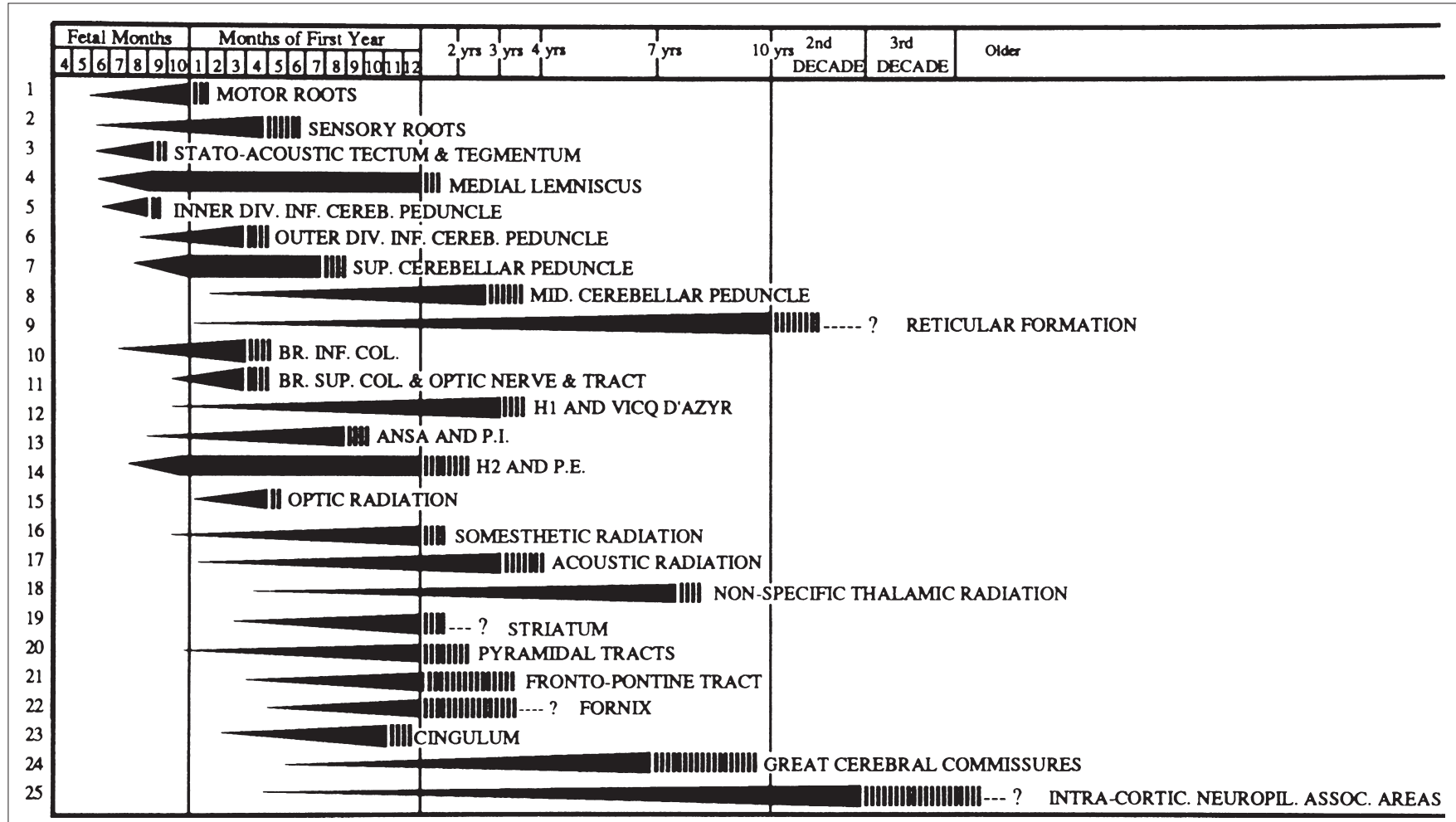

FIGURE 3 | Myelination during brain maturation in the human. From Yakovlev and Lecours (1967), with permission.

This brain maturation process of myelination and white matter volume expansion occurs simultaneously with a grey matter volume reduction (Pfefferbaum et al., 1994), and an increase in synaptogenesis which is followed by synaptic pruning and elimination (Huttenlocher, 1979). For example, Pfefferbaum showed with MRI that the volume of cortical grey matter decreases starting at 5 years of age in the human, while the white matter volume continues to increase through the third decade of life (Pfefferbaum et al., 1994). This has been confirmed and extended to include an analysis of the progression of white and grey matter changes through the complete human lifespan, in which frontal and parietal grey matter volumes peak at around 10-12 years of age and temporal grey peaks at 16-18 years of age (Thompson et al., 2005), and the white matter volume does not start to decline until after the age of 50 (Figure 4) (Sowell et al., 2003). The classic work of Huttenlocher (1979) showed that in the human medial PFC, the peak synaptic density occurs at 3-4 years of age, and starts to decline at mid-to-late adolescence. The pruning of axonal connections during brain development and maturation may be necessary for adequate formation of appropriate neuronal circuits. Thus, there is an interplay between progressive and regressive events that occur during brain maturation (Gogtay et al., 2004; Lenroot and Giedd, 2006; Sowell et al., 2003, 2004; Toga et al., 2006). In summary, the overall brain development and maturation occurs at several levels: (i) axonal, with wiring and myelination; (ii) dendritic, with arborization and spine formation; (iii) synaptic, with synaptogenesis and pruning; (iv) neuronal, with postnatal overshoot of neurons and programmed cell death; and (v) glial, with oligodendrocyte, astrocyte, and microglia maturation.

\section{BRAIN MATURATION AND SCHIZOPHRENIA}

It is possible that the regionally specific remodeling of grey and white matter that takes place into the third decade of life underlies some of the structural and functional changes that leads to the development of psychiatric disorders such as schizophrenia. The fact that the PFC matures last and that myelination is not complete until late adolescence may be significant, as the timing coincides with the typical onset of symptoms in schizophrenia. This suggests that a dysfunctional myelination process could underlie the pathogenesis of schizophrenia. Also several other psychiatric diseases, such as anxiety, mood, and personality disorders, first manifest themselves during early adulthood, possibly reflecting aberrations in brain maturation mechanisms (Paus et al., 2008). In fact, Paus and others discusses that "an exaggeration of typical adolescent changes...has occurred in patients with schizophrenia" (Keshavan et al., 1994). In fact, several of the observed neuropathologic findings in schizophrenia, such as reductions in frontal grey matter volumes (Baiano et al., 2007; Sporn et al., 2003), reductions in prefrontal metabolism (Andreasen et al., 1992), and reductions in plasma membrane phospholipid levels (Pettegrew et al., 1991) are "consistent with an exaggeration of the changes that occur in typical development" (Paus et al., 2008). Imaging work by Thompson and coworkers have also related brain maturation with the development of schizophrenia (Gogtay et al., 2008; Thompson et al., 2001).

However, it is interesting to note the lack of neurological comorbities in schizophrenia in comparison with other more typical white matter diseases. In dysmyelinating and hypomyelinating diseases such as the leukoencephalopathies, the effects of a myelin 

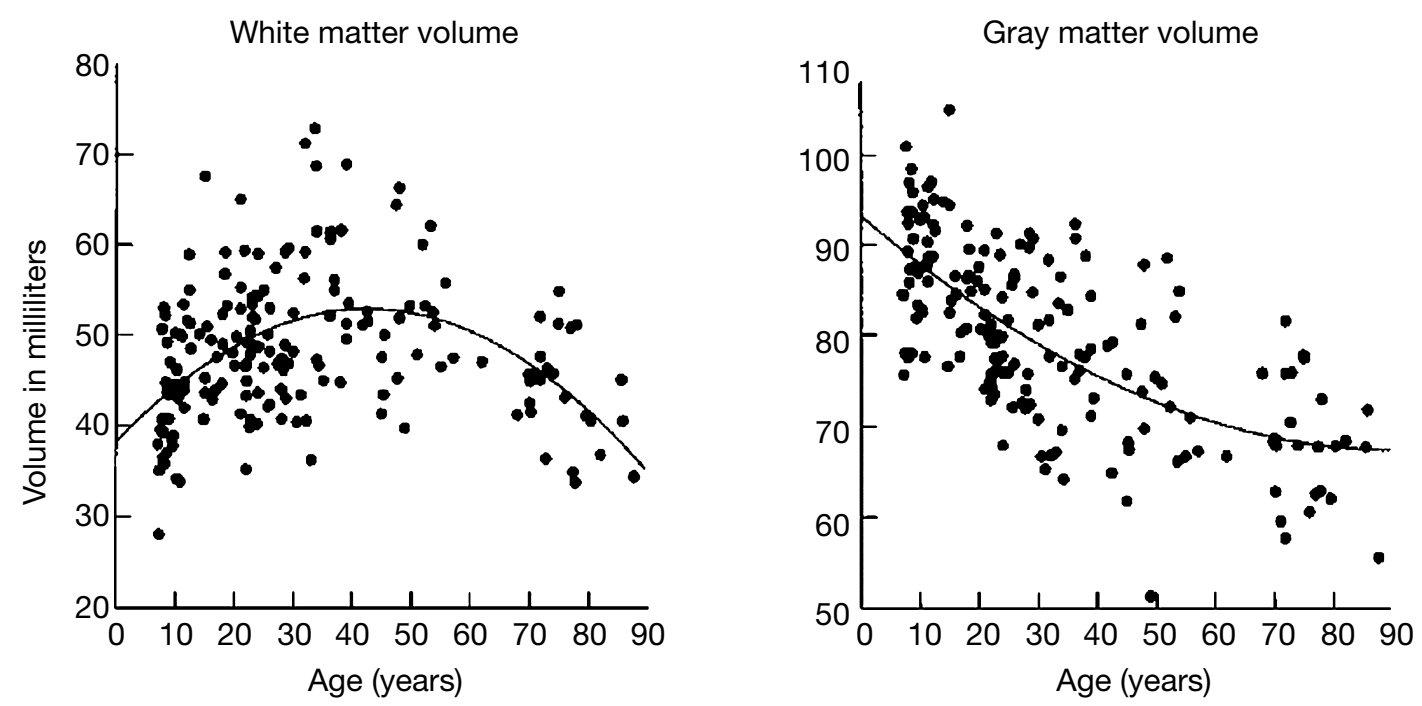

FIGURE 4 | Grey matter and white matter volumes in healthy subjects assessed with MRI. From Sowell et al. (2003), with permission.

deficiency may be striking and fatal (see reviews by Lyon et al., 2006; Schmahmann and Pandya, 2007; Schmahmann et al., 2007, 2008; Walterfang et al., 2005). If the myelin hypothesis holds true, and myelin deficiencies prove to be one of the central causes of the development of schizophrenia, one might argue and question why classic schizophrenia patients show so few neurologic symptoms. Several other white matter abnormalities often generate disturbances at the neuron level, such as seizures and/or psychomotor developmental delays. Why patients with schizophrenia do not particularly exhibit similar neurologic comorbidities, such as seizures or sensorimotor deficits, is unknown. It may be that only specific pathways become myelin-deficient, such as the late developing and poorly myelinated regions of the PFC, leading to the generation of behavioral symptoms seen in schizophrenia. Since the diverse circuits in the brain do not mature at the same time, if there is a developmental insult, this may affect only a certain population of neurons undergoing myelination, and result in a pathway-specific deficiency.

\section{GENETICS}

\section{GENETIC ASSOCIATION OF OLIGODENDROCYTE AND MYELIN-RELATED GENES IN SCHIZOPHRENIA}

In a groundbreaking study using gene microarray analysis to examine gene expression levels in postmortem samples from schizophrenia patients (Hakak et al., 2001), it was found that the expression of six myelin-related genes predominantly expressed in oligodendrocytes, including the myelin-associated glycoprotein (MAG), myelin and lymphocyte protein (MAL), 2', $3^{\prime}$-cyclic nucleotide $3^{\prime}$-phosphodiestase (CNP), gelsolin, transferrin and HER3 (ErbB3) was significantly decreased in the DLPFC in postmortem schizophrenic brains. The decreased expression of oligodendrocyterelated gene products was later confirmed and extended to other brain areas, implying that there is a pathology of oligodendrocytes underlying schizophrenia (Dracheva et al., 2006; Hakak et al., 2001; Haroutunian et al., 2006, 2007; Katsel et al., 2005a,b, 2008; McCullumsmith et al., 2007; Tkachev et al., 2003). Genetic linkage studies have also implicated myelin-related loci in schizophrenia (Bailer et al., 2000; Levinson et al., 1998) although linkage studies are now considered somewhat controversial in complex psychiatric disorders. This molecular pathology, showing a reduced myelinrelated gene expression, has been shown in the DLPFC, hippocampus, superior temporal cortex, and the cingulate gyrus (Katsel et al., 2005b; McCullumsmith et al., 2007; Sugai et al., 2004). These results from gene expression studies led to genetic association studies, to clarify whether reduced expression of oligodendrocyte and myelin genes in schizophrenia represents an early event in the etiology of the disorder, or merely result from treatment with no direct causative relation to the disorder. Much evidence, including whole genome association studies, have identified myelin- and oligodendrocyterelated genes as susceptibility genes for schizophrenia.

One of the most promising schizophrenia-related genes is neuregulin 1 (NRG1) gene (Stefansson et al., 2002, 2003; Williams et al., 2003). NRG1 and the NRG1-receptor ERBB4 are involved in several aspects of nervous system development including oligodendrocyte development (Calaora et al., 2001; Corfas et al., 2004; Sussman et al., 2005). Several lines of studies support genetic association of NRG1 with schizophrenia (Munafo et al., 2006), and associated endophenotypes (Bramon et al., 2008; Mata et al., 2009). A genetic locus-locus interactive analyses between NRG1 and ERBB4 genes provided evidence for a significant interaction between the NRG1 Icelandic schizophrenia risk haplotype and ERBB4 (Norton et al., 2006), suggesting that NRG1 may mediate its effects on schizophrenia susceptibility through functional interaction with ERBB4. Given the emerging role of NRG1 and ERRB4 in oligodendrocyte development, it is possible that alterations in NRG1 and ERBB4 affect oligodendrocytes, leading to schizophrenia.

Reticulin 4 (RTN4, also known as NOGO) is a myelin-associated protein that inhibits the outgrowth of neurites and nerve terminals. Novak et al. (2002) reported over-expression of RTN4 in the brains of people with schizophrenia and also evidence for genetic association between a marker in the $3^{\prime}$ UTR of the gene. Several groups 
have subsequently failed to replicate these genetic findings (Chen et al., 2004; Covault et al., 2004; Gregorio et al., 2005; Xiong et al., 2005), however, a moderately large study (Woo and Crowell, 2005) demonstrated modest evidence for association (Chen et al., 2004). Interestingly, three rare non-synonymous variants have recently been reported in the RTN4 receptor in schizophrenia cases but not in controls (Sinibaldi et al., 2004).

Additional genes showing reduced expression have been analyzed in genetic association studies. These genes include OLIG2 and CNP1. Olig2 is a basic helix-loop-helix (bHLH) oligodendrocyte transcription factor that, together with Olig1 is sufficient and necessary for the formation of oligodendrocytes (Ross et al., 2003; Sauvageot and Stiles, 2002). Association analysis revealed strong evidence for association for this gene. Of six informative single nucleotide polymorphisms (SNPs) analyzed, four showed genetic association (Georgieva et al., 2006), which has been further confirmed in Chinese (Huang et al., 2008), but not Japanese (Usui et al., 2006), cohorts. CNP1, encodes CNPase, which is important for process formation of oligodendrocytes (Hakak et al., 2001). The CNP1 gene maps to a region in which there is a previously reported significant linkage to schizophrenia in a single large pedigree. Significant association of a functional SNP was observed, and interestingly, this SNP is shown to be associated with low CNPase expression using allelic expression analysis in human brain (Peirce et al., 2006). This association was replicated in Caucasian (Voineskos et al., 2008), but not in Asian, cohorts (Tang et al., 2007; Usui et al., 2006). There have also been reports of genetic association between schizophrenia and myelin-oligodendrocyte glycoprotein (MOG; (Liu et al., 2005), proteolipid protein 1 (Qin et al., 2005), claudin 5 (Sun et al., 2004) and gelsolin (Xi et al., 2004). The gene encoding QKI, the quaking homologue $\mathrm{KH}$ domain RNA binding, is located in 6q25-27, and this region had been shown to be a susceptibility locus for schizophrenia as identified in a large pedigree from northern Sweden (Lindholm et al., 2001). Some evidence of genetic association was reported in this population (Aberg et al., 2006a,b), but this was not observed in a Chinese sample (Huang et al., 2009). Another gene reported to be associated with schizophrenia is MAG. MAG is a MAG that plays important roles in myelination. Support for a role for MAG in schizophrenia susceptibility has been reported in both family based and case control studies in Han Chinese populations, but still controversial.

Finally, PTPRZ1, a gene encoding receptor protein tyrosine phosphatase beta (RPTP $\beta$ ) is a new and promising candidate gene for schizophrenia (Buxbaum et al., 2008). RPTP $\beta$ is expressed in oligodendrocytes, and appears to modulate ERBB4 signaling. Association analysis of $P T P R Z 1$ showed highly significant association of this gene to schizophrenia in this first study, however, this association was not replicated in a Japanese cohort (Ito et al., 2008).

\section{MOUSE MODELS OF WHITE MATTER DYSFUNCTION}

Transgenic mouse models may serve as vehicles for studying the morphological and anatomical abnormalities that may result from a genetic defect affecting myelination. Some recent mouse models of white matter dysfunction have emerged during the last few years, which may serve as putative animal models for schizophrenia. The evidence described above are beginning to provide enough construct validity for mice with disruption of oligodendrocyte and myelin-associated genes as animal models for schizophrenia, and several knockout mice for oligodendrocyte and myelin-related genes have been investigated.

For example, CNPase knockout mice show no obvious delay in myelination and oligodendrocyte development, but develop ataxia and motor deficits at 4 months and die (Lappe-Siefke et al., 2003). A detailed histological analysis found axonal loss in these mice, a feature observed in schizophrenia. As NRG1 regulates oligodendrocyte development through ERB receptors on oligodendrocytes, Corfas and colleagues generated a mouse expressing a dominant negative ERB receptor in oligodendrocytes, and found oligodendrocyte and myelin abnormalities in this line. These mice showed reduced locomotion and social dysfunction, with increased dopamine signaling and hypersensitivity to amphetamine, reflecting aspects of the disorder (Roy et al., 2007). In the same way, mice deficient in Rtn4r have been studied, and altered locomotor activity (Hsu et al., 2007) and reduced working memory function (Budel et al., 2008) were observed. The transmembrane protease Bacel is a key molecule that regulates NRG1 signaling and myelination (Hu et al., 2006). Savonenko et al. (2008) reported that Bace1-null mice show schizophrenia-related phenotypes in multiple behavioral domains, including deficits in prepulse inhibition and novelty-induced hyperactivity, hypersensitivity to a glutamatergic psychostimulant, cognitive impairments, and deficits in social recognition. Fgfr2 is expressed in oligodendrocytes and involved in the formation of myelin membranes and Kaga et al. (2006) generated conditional knockout mice of this gene and found that conditional knockout mice are hyperactive and that dopamine receptor antagonist abolished this abnormality.

The MAG knockout model is another relevant mouse model of myelin deficits, in light of the studies that found decreased expression of MAG in schizophrenia (Hakak et al., 2001; McCullumsmith et al., 2007; Tkachev et al., 2003). MAG is known to interact with neuronal membranes where it helps maintain the periaxonal space of myelin sheaths ( $\mathrm{Li}$ et al., 1994), is involved in initiation of myelination (Montag et al., 1994), and has been shown to inhibit neurite outgrowth and impair axonal regeneration (Quarles, 2009). This has led to the hypothesis that MAG promotes maturation, maintenance and survival of myelinated neurons (Quarles, 2009). MAG knockout mice may therefore have disruptions in normal myelinated tract development that are reflected in altered anisotropy or fiber length density. Several studies have described developmental abnormalities in the MAG knockout model but have not demonstrated a dysfunctional phenotype (Li et al., 1994; Loers et al., 2004; Weiss et al., 2000, 2001). Behavioral studies of these mice showed fairly subtle abnormalities. Mice missing the Mag gene are less proficient than wild-type mice in maintaining balance on a rotating cylinder and display hyperactivity and impaired hindlimb reflex extension (Pan et al., 2005). However, the mutant mice showed no differences in spatial learning and memory or in swimming speed, as demonstrated in a Morris water maze (Montag et al., 1994).

Another mouse model recently used in research on schizophrenia is the QKI model or "Quaking” mutant (Haroutunian et al., 2006; Lauriat et al., 2008). $Q k^{\mathrm{V}}$ is an autosomal recessive mutation in mice that leads to severe dysmyelination of the CNS due to defects in oligodendrocyte maturation and RNA metabolism of myelin 
components, and all isoforms of QKI (QKI5, 6, 7) are deleted in the mice with this mutation. The "quaking" mice show reduced number of myelin lamellae, lack of myelin sheath compaction, and abnormalities in the structure of nodal regions. In addition to that, alterations of dopamine system parameters, including increased dopamine metabolism and increased dopamine $\mathrm{D}_{2}$ receptor binding, have been observed (Nikulina et al., 1995). Homozygous mice that survive to adulthood exhibit a characteristic tremor or "quaking" (Sidman et al., 1964), with abnormal composition and structure of myelin (Baumann and Pham-Dinh, 2001).As a homozygote, this mouse has traditionally been used in epilepsy research in virtue of its myelin and conduction abnormalities, whereas the heterozygote has a milder form of white matter dysfunction, and has been used as a putative schizophrenia model (Aberg et al., 2006a,b). The QKI gene product is an mRNA binding protein involved in determination of glial fate and oligodendrocyte differentiation (Ebersole et al., 1996; Larocque and Richard, 2005) and has been implicated in schizophrenia in several studies (Chenard and Richard, 2008; McCullumsmith et al., 2007; McInnes and Lauriat, 2006), in addition to the genetic studies cited above.

Mice treated with cuprizone, a drug that induces demyelination, demonstrated altered behavior including hyperactivity, sensorimotor gating anomalies, and memory alterations (Franco-Pons et al., 2007). Interestingly, these defects lasted after the discontinuation of cuprizone treatment, suggesting developmental insults to oligodendrocytes and myelin might contribute to schizophrenia. Zhang et al. found that the atypical antipsychotic, quetiapine, promoted the differentiation of oligodendrocyte lineage cells and prevented cortical demyelination and the concomitant spatial working memory impairment induced by cuprizone ( $\mathrm{Xu}$ et al., 2009; Zhang et al., 2008).

\section{RECENT MORPHOLOGICAL FINDINGS FROM TRANSGENIC MICE}

To date, two mouse models have been investigated for morphological alterations: the MAG model and the QKI model. Hof and coworkers examined two measures of white matter integrity in the MAG knockout model (Höistad et al., 2008; Segal, 2008). The cingulum bundle was examined using both DTI to examine white matter coherence as well as histological techniques to measure myelinated fiber length density. Diffusion anisotropy imaging was performed in adult MAG knockout mice, measuring the FA in a region of the cingulum bundle. At matched histological levels, using sections stained for myelin with Black Gold (Schmued and Slikker, 1999), myelinated fiber length density, defined as fiber length per unit of white matter volume was evaluated (Figure 5). The MAG knockout model displayed no alterations in either FA or fiber length density in the cingulum bundle (Segal, 2008). Thus, the effects of dysmyelination in the MAG model may be very subtle and may require ultrastructural studies to pinpoint the precise neuropathologic alterations.

We also performed morphological analysis of regional overall changes in cytoarchitecture in the ACC of the MAG and QKI mouse models (Höistad et al., 2008). Using stereologic methods, the number, density and spatial distribution patterns of neurons and oligodendrocytes were investigated. The effects of dysmyelination on neuron and oligodendrocyte numbers and densities in the ACC in these models revealed slight decreases in the overall volume

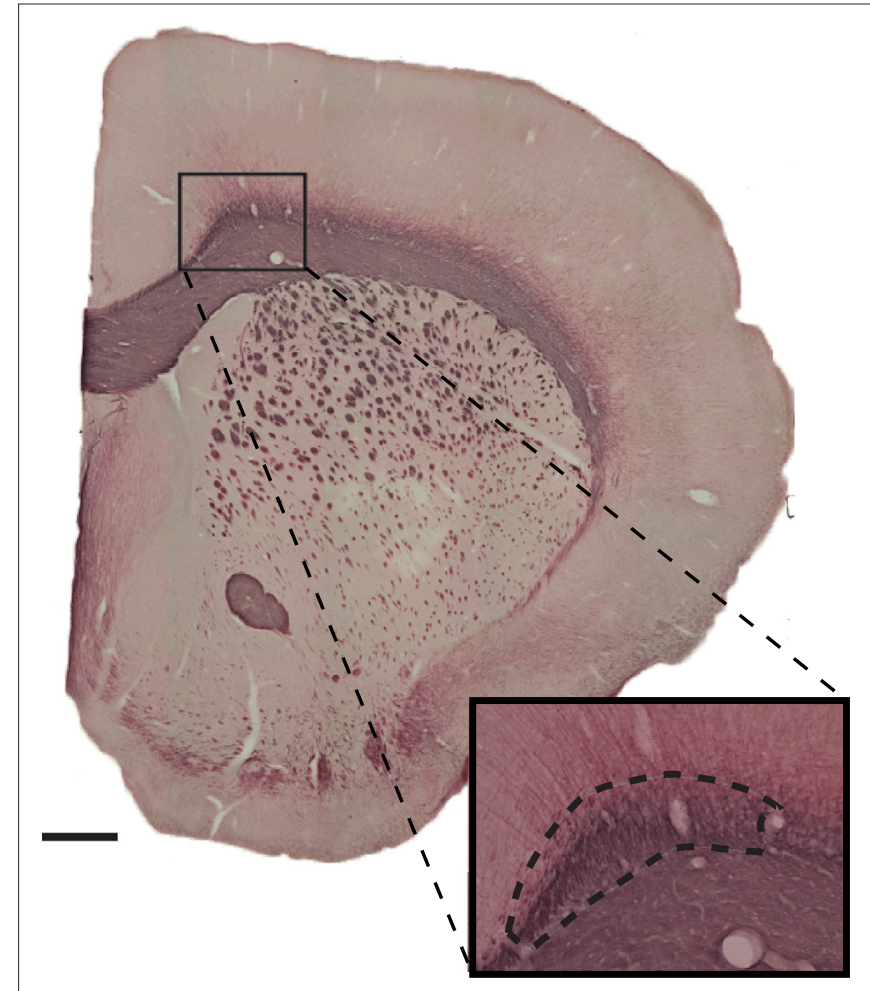

FIGURE 5 | Low magnification photomicrograph of a myelin Black Gold stain of a wild-type mouse. Inset depicts the outlined cingulum bundle for analysis of fiber length density. Scale bar $50 \mu \mathrm{m}$.

of the ACC. Both the MAG and the QKI mouse models displayed lower total neuron numbers, but no difference in estimates of neuronal density, and differences in oligodendrocytes in the ACC were observed only as a trend in the QKI model. Thus, the QKI model may prove to be a more valuable model of myelin deficiencies than the MAG model, especially considering the absence of changes in the FA and fiber length density in this model.

Furthermore, we analyzed the dendritic structure of pyramidal neurons in these mouse models to assess whether disrupted myelination of axonal pathways that provide inputs to the neocortex severely affect the dendritic integrity of target neurons, resulting in dendritic attrition, loss of dendritic spines, and alterations in spine morphology. This permits an evaluation of the effect of abnormal myelination on the structure and function of pyramidal neurons in select regions relevant to schizophrenia, for example the medial PFC. The hypothesis we are investigating is elucidating potential morphological effects on target neurons, as a consequence of myelin deficiencies in the afferent axonal tracts (Segal et al., 2007b). Single pyramidal neurons were injected with a fluorescent dye and then analyzed morphometrically.

In the MAG model, analyses of pyramidal neurons in layers II and III in the PFC have shown that in young mice (3 months) the basal dendrites showed a reduced level of dendritic branching compared to their wild-type littermates (Segal et al., 2007b), while less remarkable effects were observed on the apical branches. This may suggest that the dendritic tree of the MAG mice is undergoing a selective pathology that may be related to alterations in 
specific axonal pathways influencing principally the basal dendrites, and as such possibly of thalamic origin. These data imply that a disturbance in the organization of myelin, due to impaired expression of MAG, may result in alterations in morphology of layers II and III pyramidal cells, particularly with respect to basal dendritic integrity. Such alterations may lead to abnormalities of specific white matter tracts and affect the prefrontal circuits. Preliminary observations of spine densities in young MAG mice have so far not revealed differences between knockout and control mice (Segal et al., 2007b). However spine pathology may be more prominent in aged mice as a function of aging per se.

In the QKI model, analyses of pyramidal neurons in layers II and III in the ACC of old mice showed shorter dendritic lengths of both apical and basal dendrites (Höistad et al., 2008). The apical dendrites displayed shorter dendritic lengths distal from the soma, fewer numbers of branch radial intersections, and fewer higher order branches, whereas no differences were observed in the basal dendrites (Figures 6A-D). Preliminary observations of spine densities in the QKI mouse has suggested that dendritic spines are in fact more numerous in QKI mice compared to control littermates (Figures 6E-H). This may reflect compensatory mechanisms similar to sprouting. These observations are in line with our stereologic findings, which demonstrate that the QKI mice exhibit lower total neuron numbers and lower volumes of the ACC than control mice.

The preliminary evidence presented in Figure 6 on the QKI model, suggests possible support for the viability of the hypothesis that myelin deficiencies may have morphological effects on target neurons, although the extent of these effects are not fully analyzed. We are aware of the fact that the relationship between disrupted myelin and changes in spine densities may not appear as a direct or causal one. It remains plausible that deficits in myelination may cause significant alterations in connectivity of select components of the afferent systems to cortical neurons, and as a result, a partial differentiation of those targets, which may alter the spine densities and spine morphologies. Comparably, detrimental changes in spine densities have been found during aging and in stress conditions (Duan et al., 2003; Radley et al., 2008).The possibility that myelin and oligodendrocyte changes impact on the integrity of the pyramidal neuron dendritic tree fits well within the general context of the effects of white matter disruption in the brain.

\section{FUTURE DIRECTIONS}

Evidence from very different lines of research supports the premise that dysfunction of oligodendrocytes is a critical factor in the development of schizophrenia. The precise role oligodendrocytes hold in the cascade of malfunctions that results in the constellation of deficits seen in the disease is still unknown. Layers II and III pyramidal neurons in the ACC may be the targets of axonal pathways affected in schizophrenia. Quantitative information on neuronal integrity in mouse models is important for understanding downstream effects of myelin genetic abnormalities, and to assess the validity of models in the context of observable neuropathologic changes in human brains. These studies need to be extended to additional models reflecting the genetic complexity of schizophrenia, and electron microscopy studies should be used further to assess structural aberrations in oligodendrocytes
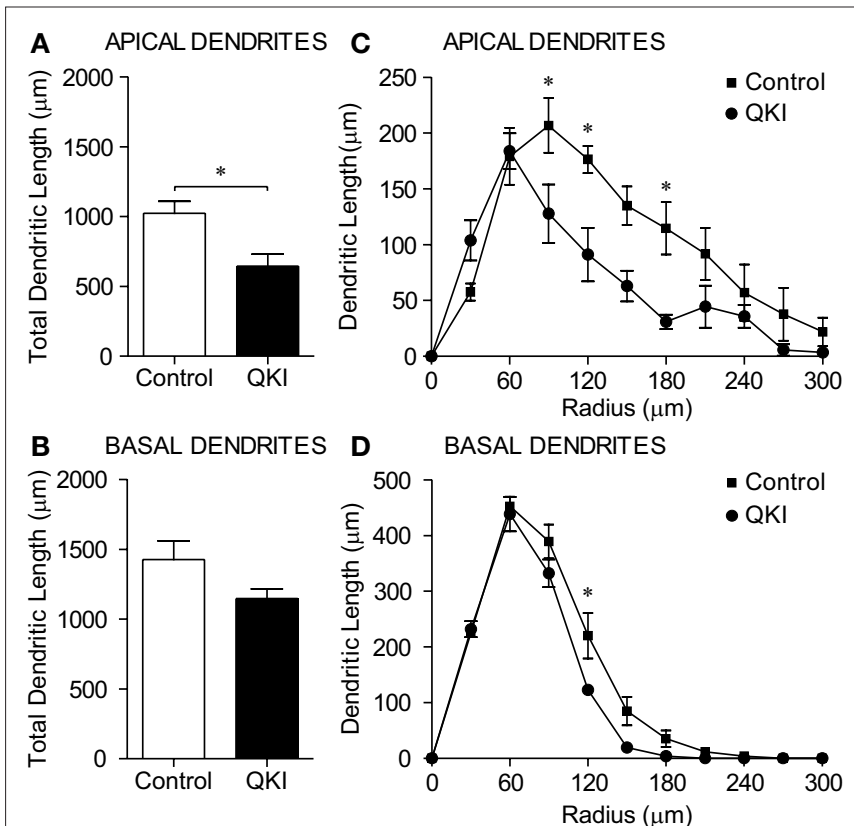

BASAL DENDRITES
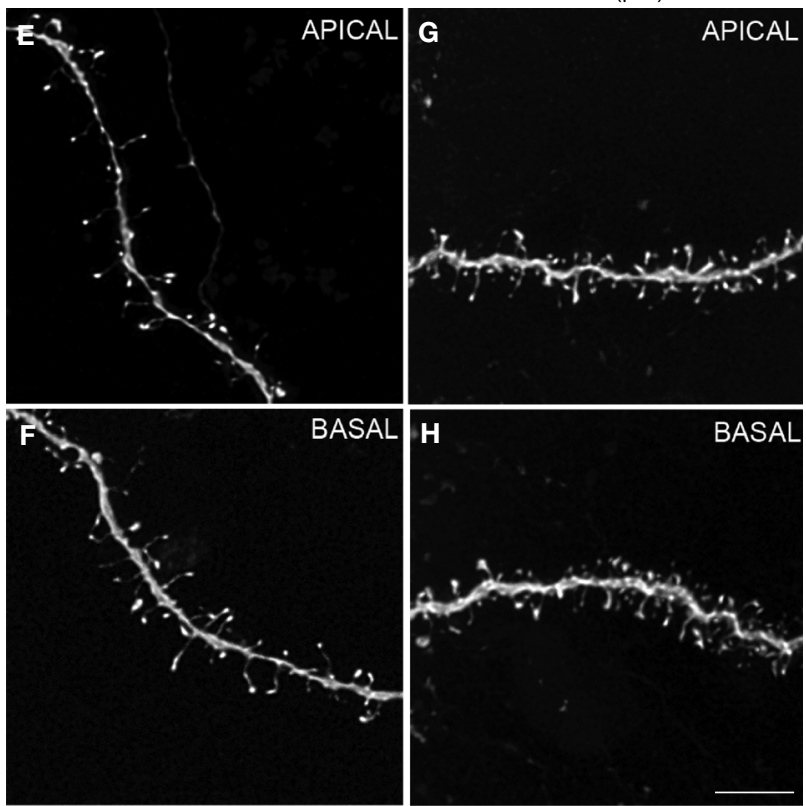

control

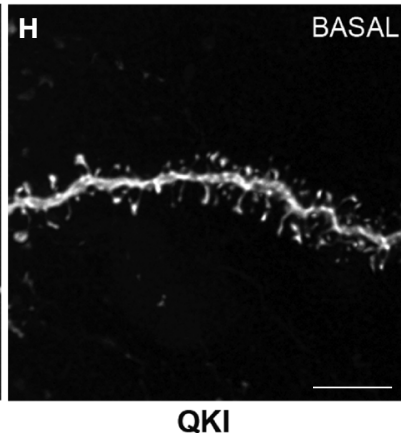

FIGURE 6 | Dendritic arbors and spines in the control and QKI mouse model. (A,B) Arbor analysis showing total dendritic lengths in apical and basal dendrites, ${ }^{*} p<0.05$, Student's t-test. (C,D) Dendritic lengths in apical and basal dendrites, as a function of the radial distance from the cell soma, ${ }^{*} p<0.05$, two-way ANOVA with Bonferroni's post hoc test (Höistad et al. 2008). (E-H) Dendritic segments of Lucifer yellow-filled neurons in the medial PFC were scanned at high resolution on a confocal laser scanning microscope. 3-Dimentionally reconstructed dendritic segments, 50-100 $\mu \mathrm{m}$ from the cell soma, show hyperspiny dendrites on both the apical and basal branches in the QKI mouse. Scale bar $5 \mu \mathrm{m}$.

and myelin sheaths, as well as immunogold approaches to study synaptic integrity by visualizing pre- and postsynaptic proteins. Correlative morphology and density analyses of dendritic spines will help clarify plastic changes in responses to myelin challenges. 
The data obtained in transgenic mice will offer critical correlates to neuropathologic features that can be analyzed in postmortem human materials. Combined analysis of human specimen and relevant mouse models offers a unique opportunity to investigate myelin deficits that have a clinical impact. As a result of such combined approaches, a model of schizophrenia with characterized molecular defects that can be used for developing therapeutic approaches will hopefully emerge.

\section{REFERENCES}

Aberg, K., Saetre, P., Jareborg, N., and Jazin, E. (2006a).Human QKI, a potential regulator of mRNA expression of human oligodendrocyte-related genes involved in schizophrenia. Proc. Natl. Acad. Sci. U. S. A. 103, 7482-7487.

Aberg, K., Saetre, P., Lindholm, E., Ekholm, B., Pettersson, U., Adolfsson, R., and Jazin, E. (2006b). Human QKI, a new candidate gene for schizophrenia involved in myelination. Am. J. Med. Genet. B Neuropsychiatr. Genet. 141, 84-90.

Akbarian, S., Kim, J. J., Potkin, S. G., Hetrick, W. P., Bunney, W. E. Jr, and Jones, E. G. (1996). Maldistribution of interstitial neurons in prefrontal white matter of the brains of schizophrenic patients. Arch. Gen. Psychiatry 53, 425-436.

Amodio, D. M., and Frith, C. D. (2006). Meeting of minds: the medial frontal cortex and social cognition. Nat. Rev. Neurosci. 7, 268-277.

Anderson, S. A., Volk, D. W., and Lewis, D. A. (1996). Increased density of microtubule associated protein 2-immunoreactive neurons in the prefrontal white matter of schizophrenic subjects. Schizophr. Res. 19, 111-119.

Andreasen, N., Nasrallah, H. A., Dunn, V., Olson, S. C., Grove, W. M., Ehrhardt, J. C., Coffman, J. A., and Crossett, J. H. (1986). Structural abnormalities in the frontal system in schizophrenia. A magnetic resonance imaging study. Arch. Gen. Psychiatry 43, 136-144.

Andreasen, N. C., Rezai, K., Alliger, R., Swayze, V.W.II, Flaum, M., Kirchner, P., Cohen, G., and O'Leary, D. S. (1992). Hypofrontality in neuroleptic-naive patients and in patients with chronic schizophrenia. Assessment with xenon 133 single-photon emission computed tomography and the Tower of London. Arch. Gen. Psychiatry 49, 943-958.

Baiano, M., David, A., Versace, A., Churchill, R., Balestrieri, M., and Brambilla, P. (2007). Anterior cingulate volumes in schizophrenia: a systematic review and a meta-analysis of MRI studies. Schizophr. Res. 93, 1-12.

Bailer, U., Leisch, F., Meszaros, K., Lenzinger, E., Willinger, U., Strobl, R., Gebhardt, C., Gerhard, E., Fuchs, K.,
Sieghart, W., Kasper, S., Hornik, K., and Aschauer, H. N. (2000). Genome scan for susceptibility loci for schizophrenia. Neuropsychobiology 42, 175-182.

Ballesteros, M. C., Hansen, P. E., and Soila, K. (1993). MR imaging of the developing human brain. Part 2. Postnatal development. Radiographics 13, 611-622.

Baumann, N., and Pham-Dinh, D. (2001). Biology of oligodendrocyte and myelin in the mammalian central nervous system. Physiol. Rev. 81, 871-927.

Beckmann, M., Johansen-Berg, H., and Rushworth, M. F. (2009). Connectivity-based parcellation of human cingulate cortex and its relation to functional specialization. J. Neurosci. 29, 1175-1190.

Benes, F. M. (2000). Emerging principles of altered neural circuitry in schizophrenia. Brain Res. Brain Res. Rev. 31, 251-269.

Benes, F. M., McSparren, J., Bird, E. D., SanGiovanni, J. P., and Vincent, S. L. (1991). Deficits in small interneurons in prefrontal and cingulate cortices of schizophrenic and schizoaffective patients. Arch. Gen. Psychiatry 48, 996-1001.

Bramon, E., Dempster, E., Frangou, S., Shaikh, M., Walshe, M., Filbey, F. M., McDonald, C., Sham, P., Collier, D. A., and Murray, R. (2008). Neuregulin-1 and the P300 waveform: a preliminary association study using a psychosis endophenotype. Schizophr. Res. 103, 178-185.

Broadbelt, K., Byne, W., and Jones, L. B. (2002). Evidence for a decrease in basilar dendrites of pyramidal cells in schizophrenic medial prefrontal cortex. Schizophr. Res. 58, 75-81.

Buchsbaum, M. S., Buchsbaum, B. R., Hazlett, E. A., Haznedar, M. M., Newmark, R., Tang, C.Y., and Hof, P. R. (2007). Relative glucose metabolic rate higher in white matter in patients with schizophrenia. Am. J. Psychiatry 164, 1072-1081.

Buchsbaum, M. S., Friedman, J., Buchsbaum, B. R., Chu, K. W., Hazlett, E. A., Newmark, R., Schneiderman, J. S., Torosjan, Y., Tang, C., Hof, P. R., Stewart, D., Davis, K. L., and Gorman, J. (2006).

\section{ACKNOWLEDGEMENTS}

We thank Drs D. Carpenter, C.Y. Tang, M.S. Buchsbaum, and M. Gama Sosa for their participation in our studies and helpful discussion. This work was supported by grants from NIH MH66392 (Joseph D. Buxbaum, Takeshi Sakurai, and Patrick R. Hof), MH58911 (Patrick R. Hof), and MH82862 (Devorah Segal), and by a postdoctoral fellowship from the Swedish Brain Foundation to Malin Hoistad.

Diffusion tensor imaging in schizophrenia. Biol. Psychiatry 60, 1181-1187.

Buchsbaum, M. S., Tang, C. Y., Peled, S. Gudbjartsson,H., Lu, D., Hazlett, E. A. Downhill, J., Haznedar, M. Fallon, J. H., and Atlas, S. W. (1998). MRI white matter diffusion anisotropy and PET metabolic rate in schizophrenia. Neuroreport 9, 425-430.

Budel, S., Padukkavidana, T., Liu, B. P. Feng, Z., Hu, F., Johnson, S., Lauren, J., Park, J. H., McGee, A. W., Liao, J. Stillman, A., Kim, J. E., Yang, B. Z. Sodi, S., Gelernter, J., Zhao, H. Hisama, F., Arnsten, A. F., and Strittmatter, S.M. (2008). Genetic variants of Nogo-66 receptor with possible association to schizophrenia block myelin inhibition of axon growth J. Neurosci. 28, 13161-13172.

Bush, G., Luu, P., and Posner, M. I. (2000). Cognitive and emotional influences in anterior cingulate cortex. Trends $\operatorname{Cog} n$. Sci. 4, 215-222.

Buxbaum, J. D., Georgieva, L., Young, J. J., Plescia, C., Kajiwara, Y., Jiang, Y., Moskvina, V., Norton, N., Peirce, T., Williams, H., Craddock, N. J., Carroll, L., Corfas, G., Davis, K. L., Owen, M. J., Harroch, S., Sakurai, T. and O'Donovan, M. C. (2008). Molecular dissection of NRG1ERBB4 signaling implicates PTPRZ1 as a potential schizophrenia susceptibility gene. Mol. Psychiatry 13 162-172.

Calaora, V., Rogister, B., Bismuth, K. Murray, K., Brandt, H., Leprince, P., Marchionni,M., andDubois-Dalcq, M (2001). Neuregulin signaling regulates neural precursor growth and the generation of oligodendrocytes in vitro. J. Neurosci. 21, 4740-4751.

Casanova, M. F., de Zeeuw, L., Switala, A. Kreczmanski, P., Korr, H., Ulfig, N., Heinsen, H., Steinbusch, H. W., and Schmitz, C. (2005). Mean cell spacing abnormalities in the neocortex of patients with schizophrenia. Psychiatry Res. 133, 1-12.

Casanova, M. F., Kreczmanski, P. Trippe, J. II, Switala, A., Heinsen, H., Steinbusch, H. W., and Schmitz, C. (2008). Neuronal distribution in the neocortex of schizophrenic patients. Psychiatry Res. 158, 267-277.
Casey, B. J., Tottenham, N., Liston, C., and Durston, S. (2005). Imaging the developing brain: what have we learned about cognitive development? Trends Cogn. Sci. 9, 104-110.

Chen, W., Gu, N., Duan, S., Sun, Y., Zheng, Y., Li,C., Pan,Y., Xu, Y., Feng, G., and He, L. (2004). No association between the genetic polymorphisms within RTN4 and schizophrenia in the Chinese population. Neurosci. Lett. 365, 23-27.

Chenard, C. A., and Richard, S. (2008). New implications for the QUAKING RNA binding protein in human disease. J. Neurosci. Res. 86, 233-242.

Chun, J. J., and Shatz, C. J. (1989). Interstitial cells of the adult neocortical white matter are the remnant of the early generated subplate neuron population. J. Comp. Neurol. 282, 555-569.

Corfas, G., Roy, K., and Buxbaum, J. D. (2004). Neuregulin 1-erbB signaling and the molecular/cellular basis of schizophrenia. Nat. Neurosci. 7, 575-580.

Covault, J., Lee, J., Jensen, K., and Kranzler, H. (2004). Nogo 3'-untranslated region CAA insertion: failure to replicate association with schizophrenia and demonstration of marked population difference in frequency of the insertion. Brain Res. Mol. Brain Res. 120, 197-200.

Csernansky, J. G., Gillespie, S. K., Dierker, D. L., Anticevic, A., Wang, L., Barch, D. M., and Van Essen, D. C. (2008). Symmetric abnormalities in sulcal patterning in schizophrenia. Neuroimage 43, 440-446.

Davis, K. L., Stewart, D. G., Friedman, J. I., Buchsbaum, M., Harvey, P. D. Hof, P. R., Buxbaum, J., and Haroutunian, V. (2003). White matter changes in schizophrenia: evidence for myelin-related dysfunction. Arch. Gen. Psychiatry 60, 443-456.

Denier, C., Orgibet, A., Roffi, F., Jouvent, E., Buhl,C., Niel, F., Boespflug-Tanguy, O., Said, G., and Ducreux, D. (2007). Adult-onset vanishing white matter leukoencephalopathy presenting as psychosis. Neurology 68, 1538-1539.

Devinski, O., and Luciano, D. (1993). The contributions of cingulate cortex to human behavior. In Neurobiology 
of Cingulate Cortex and Limbic Thalamus, B. A. Vogt and M. Gabriel, eds (Boston, Birkhauser), pp. 527-556.

Devinsky, O., Morrell, M. J., and Vogt, B. A. (1995). Contributions of anterior cingulate cortex to behaviour. Brain 118(Pt 1), 279-306.

Dracheva, S., Davis, K. L., Chin, B., Woo, D. A., Schmeidler, J., and Haroutunian, V. (2006). Myelinassociated mRNA and protein expression deficits in the anterior cingulate cortex and hippocampus in elderly schizophrenia patients. Neurobiol. Dis. 21, 531-540.

Duan, H., Wearne, S. L., Rocher, A. B., Macedo, A., Morrison, J. H., and Hof, P. R. (2003). Age-related dendritic and spine changes in corticocortically projecting neurons in macaque monkeys. Cereb. Cortex 13, 950-961.

Dwork, A. J., Mancevski, B., and Rosoklija, G. (2007). White matter and cognitive function in schizophrenia. Int. J. Neuropsychopharmacol. 10, 513-536.

Eastwood, S. L., and Harrison, P. J. (1995). Decreased synaptophysin in the medial temporal lobe in schizophrenia demonstrated using immunoautoradiography. Neuroscience 69, 339-343.

Ebersole, T. A., Chen, Q., Justice, M. J., and Artzt, K. (1996). The quaking gene product necessary in embryogenesis and myelination combines features of RNA binding and signal transduction proteins. Nat. Genet. 12, 260-265.

Fallon, J.H., Opole, I. O., and Potkin, S. G. (2003). The neuroanatomy of schizophrenia: circuitry and neurotransmitter systems. Clin. Neurosci. Res. 3 , 77-107.

Flechsig, P. (1901). Developmental (myelogenetic) localisation of the cerebral cortex in the human. Lancet 158, 1027-1030.

Flynn, S. W., Lang, D. J., Mackay, A. L., Goghari, V., Vavasour, I. M., Whittall, K. P., Smith, G. N., Arango, V., Mann, J. J., Dwork, A. J., Falkai, P., and Honer, W. G. (2003). Abnormalities of myelination in schizophrenia detected in vivo with MRI, and post-mortem with analysis of oligodendrocyte proteins. Mol. Psychiatry 8, 811-820.

Foong, J., Maier, M., Barker, G. J., Brocklehurst, S., Miller, D. H., and Ron, M. A. (2000). In vivo investigation of white matter pathology in schizophrenia with magnetisation transfer imaging. J. Neurol. Neurosurg. Psychiatr. 68, 70-74.

Foong, J., Symms, M. R., Barker, G. J., Maier, M., Woermann, F. G., Miller, D. H., and Ron, M. A. (2001). Neuropathological abnormalities in schizophrenia: evidence from magnetization transfer imaging. Brain $124,882-892$.

Franco-Pons, N., Torrente, M., Colomina, M. T., and Vilella, E. (2007). Behavioral deficits in the cuprizoneinduced murine model of demyelination/remyelination. Toxicol. Lett. 169, 205-213.

Fujiwara, H., Namiki, C., Hirao, K., Miyata, J., Shimizu, M., Fukuyama, H., Sawamoto, N., Hayashi, T., and Murai, T. (2007). Anterior and posterior cingulum abnormalities and their association with psychopathology in schizophrenia: a diffusion tensor imaging study. Schizophr. Res. 95, 215-222.

Fuster, J. M. (2002). Frontal lobe and cognitive development. J. Neurocytol. 31, 373-385.

Garey, L. J., Ong, W. Y., Patel, T. S., Kanani, M., Davis,A., Mortimer, A. M., Barnes, T. R., and Hirsch, S. R. (1998). Reduced dendritic spine density on cerebral cortical pyramidal neurons in schizophrenia. J. Neurol. Neurosurg. Psychiatr. 65, 446-453.

Georgieva, L., Moskvina, V., Peirce, T., Norton, N., Bray, N. J., Jones, L., Holmans, P., Macgregor,S.,Zammit, S., Wilkinson, J., Williams, H., Nikolov, I., Williams, N., Ivanov, D., Davis, K. L., Haroutunian, V., Buxbaum, J. D., Craddock,N.,Kirov, G.,Owen,MJ., and O’Donovan, M.C. (2006). Convergent evidence that oligodendrocyte lineage transcription factor 2 (OLIG2) and interacting genes influence susceptibility to schizophrenia. Proc. Natl. Acad. Sci. U. S. A. 103, 12469-12474.

Gibson, K., and Petersen, A. (1991). Brain Maturation and Cognitive Development: Comparative and Cross-cultural Perspectives. New York, Aldine de Gruyter.

Gilles,F.H.,Shankle,W., and Dooling, E. C. (1983). Myelinated tracts: growth patterns. In The Developing Human Brain, F. H. Gilles, A. Leviton, and E. C. Dooling, eds (London, John Wright PSG Inc.), pp. 117-183.

Glantz, L. A., and Lewis, D. A. (1997). Reduction of synaptophysin immunoreactivity in the prefrontal cortex of subjects with schizophrenia. Regional and diagnostic specificity. Arch. Gen. Psychiatry 54, 943-952.

Glantz, L. A., and Lewis, D. A. (2000). Decreased dendritic spine density on prefrontal cortical pyramidal neurons in schizophrenia. Arch. Gen. Psychiatry 57, 65-73.

Glees, P., Cole, J., Whitty, C. W., and Cairns, H. (1950). The effects of lesions in the cingular gyrus and adjacent areas in monkeys. J. Neurol. Neurosurg. Psychiatr. 13, 178-190.
Gogtay, N., Giedd, J. N., Lusk, L., Hayashi, K. M., Greenstein, D., Vaituzis, A. C., Nugent, T. F. III, Herman, D. H., Clasen, L. S., Toga, A. W., Rapoport, J. L., and Thompson, P. M. (2004). Dynamic mapping of human cortical development during childhood through early adulthood. Proc. Natl. Acad. Sci. U. S. A. 101, 8174-8179.

Gogtay, N., Lu, A., Leow, A. D., Klunder, A. D., Lee, A. D., Chavez, A. Greenstein,D., Giedd,J.N., Toga, A. W., Rapoport, J. L., and Thompson, P. M. (2008). Three-dimensional brain growth abnormalities in childhoodonset schizophrenia visualized by using tensor-based morphometry. Proc. Natl. Acad. Sci. U. S. A. 105, 15979-15984.

Gregorio, S. P., Mury, F. B., Ojopi, E. B., Sallet, P.C., Moreno, D. H., Yacubian, J., Tavares, H., Santos, F. R., Gattaz, W. F., and Dias-Neto, E. (2005). Nogo CAA $3^{\prime}$ UTR Insertion polymorphism is not associated with Schizophrenia nor with bipolar disorder. Schizophr. Res. 75, 5-9.

Hadland, K. A., Rushworth, M. F., Gaffan, D., and Passingham, R. E. (2003). The effect of cingulate lesions on social behaviour and emotion. Neuropsychologia 41, 919-931.

Hakak, Y., Walker,J.R.,Li, C., Wong, W. H., Davis, K. L., Buxbaum, J. D., Haroutunian, V., and Fienberg, A. A. (2001). Genome-wide expression analysis reveals dysregulation of myelination-related genes in chronic schizophrenia. Proc. Natl. Acad. Sci. U. S. A. $98,4746-4751$.

Haroutunian, V., Katsel, P., Dracheva, S., and Davis, K. L. (2006). The human homolog of the QKI gene affected in the severe dysmyelination "quaking" mouse phenotype: downregulated in multiple brain regions in schizophrenia. Am. J. Psychiatry 163, 1834-1837.

Haroutunian, V., Katsel, P., Dracheva, S. Stewart, D. G., and Davis, K. L. (2007). Variations in oligodendrocyte-related gene expression across multiple cortical regions: implications for the pathophysiology of schizophrenia. Int. $J$. Neuropsychopharmacol. 10, 565-573.

Haznedar, M. M., Buchsbaum, M. S. Hazlett,E. A., Shihabuddin, L., New, A., and Siever, L. J. (2004). Cingulate gyrus volume and metabolism in the schizophrenia spectrum. Schizophr. Res. 71, 249-262.

Hof, P. R., Haroutunian, V., Friedrich, V. L. Jr, Byne, W., Buitron, C., Perl, D. P., and Davis, K. L. (2003). Loss and altered spatial distribution of oligodendrocytes in the superior frontal gyrus in schizophrenia. Biol. Psychiatry 53, 1075-1085.
Höistad, M., Segal, D., Carpenter, D., Tang, C. Y., and Hof, P. R. (2008). The effects of myelin deficiencies in mouse models of schizophrenia: studies in the MAG knockout and the quaking mutant. Washington, DC, SFN (abstract 254.25).

Honea, R., Crow, T. J., Passingham, D., and Mackay, C. E. (2005). Regional deficits in brain volume in schizophrenia: a meta-analysis of voxel-based morphometry studies. Am. J. Psychiatry $162,2233-2245$

Honea, R. A., Meyer-Lindenberg, A., Hobbs, K. B., Pezawas, L., Mattay, V. S., Egan, M. F., Verchinski, B., Passingham, R. E., Weinberger, D. R., and Callicott, J. H. (2008). Is gray matter volume an intermediate phenotype for schizophrenia? A voxel-based morphometry study of patients with schizophrenia and their healthy siblings. Biol. Psychiatry 63, 465-474.

Hsu, R., Woodroffe, A., Lai, W.S., Cook, M. N., Mukai, J., Dunning, J. P., Swanson, D. J., Roos, J. L. Abecasis, G. R., Karayiorgou, M., and Gogos, J. A. (2007). Nogo Receptor 1 (RTN4R) as a candidate gene for schizophrenia: analysis using human and mouse genetic approaches. PLoS ONE 2, e1234.

Hu, X., Hicks, C. W., He, W., Wong, P., Macklin, W. B., Trapp, B.D., and Yan, R. (2006). Bacel modulates myelination in the central and peripheral nervous system. Nat. Neurosci. 9, 1520-1525.

Huang, K., Tang, W., Tang, R., Xu, Z., He, Z., Li, Z., Xu, Y., Li, X., He, G., Feng, G., He, L., and Shi, Y. (2008). Positive association between OLIG2 and schizophrenia in the Chinese Han population. Hum. Genet. 122, 659-660.

Huang, K., Tang, W., Xu, Z., Li, Z., He, Z., Tang, R., Che, R., Xu, Y., Li, X., Feng, G., He, L., and Shi, Y. (2009). No association found between the promoter variations of QKI and schizophrenia in the Chinese population. Prog. Neuropsychopharmacol. Biol. Psychiatry 33, 33-36.

Huttenlocher, P. R. (1979). Synaptic density in human frontal cortex - developmental changes and effects of aging. Brain Res. 163, 195-205.

Ito, Y., Yamada, S., Takahashi, N., Saito, S., Yoshimi, A., Inada, T., Noda, Y., and Ozaki, N. (2008). No association between the protein tyrosine phosphatase, receptor-type,ZPolypeptide 1 (PTPRZ1) gene and schizophrenia in the Japanese population. Am. J. Med. Genet. B Neuropsychiatr. Genet. 147B, 1013-1018.

Iversen, S. (1984). Cortical monoamines and behavior. In Monomaine Innervation of Cerebral Cortex, L. 
Descarries, T. R. Reader, and H. H. Jasper, eds (New York, NY, Alan R. Liss, Inc.), pp. 321-349.

Jones, E. G., and Powell, T. P. (1970). An anatomical study of converging sensory pathways within the cerebral cortex of the monkey. Brain 93, 793-820.

Jungerius, B. J., Hoogendoorn, M. L., Bakker, S. C., Van't Slot, R., Bardoel, A. F., Ophoff, R. A., Wijmenga, C., Kahn, R.S., and Sinke, R. J. (2008). An association screen of myelin-related genes implicates the chromosome 22q11 PIK4CA gene in schizophrenia. Mol. Psychiatry 13, 1060-1068.

Jürgens, U., Maurus, M., Ploog, D., and Winter, P. (1967). Vocalization in the squirrel monkey (Saimiri sciureus) elicited by brain stimulation. Exp. Brain Res. 4, 114-117.

Kaga, Y., Shoemaker, W. J., Furusho, M., Bryant, M., Rosenbluth, J., Pfeiffer, S. E., Oh, L., Rasband, M., Lappe-Siefke, C., Yu, K., Ornitz, D. M., Nave, K. A., and Bansal, R. (2006). Mice with conditional inactivation of fibroblast growth factor receptor-2 signaling in oligodendrocytes have normal myelin but display dramatic hyperactivity when combined with Cnpl inactivation. J. Neurosci. 26, 12339-12350.

Karoutzou, G., Emrich, H. M., and Dietrich, D. E. (2008). The myelinpathogenesis puzzle in schizophrenia: a literature review. Mol. Psychiatry 13, 245-260.

Katsel, P., Davis, K. L., Gorman, J. M., and Haroutunian, V. (2005a). Variations in differential gene expression patterns across multiple brain regions in schizophrenia. Schizophr. Res. 77, 241-252.

Katsel, P., Davis, K. L., and Haroutunian, V. (2005b). Variations in myelin and oligodendrocyte-related gene expression across multiple brain regions in schizophrenia: a gene ontology study. Schizophr. Res. 79, 157-173.

Katsel, P., Davis, K. L., Li, C., Tan, W., Greenstein, E., Kleiner Hoffman, L. B., and Haroutunian, V. (2008). Abnormal indices of cell cycle activity in schizophrenia and their potential association with oligodendrocytes. Neuropsychopharmacology 33, 2993-3009.

Keshavan, M. S., Anderson, S., and Pettegrew, J. W. (1994). Is schizophrenia due to excessive synaptic pruning in the prefrontal cortex? The Feinberg hypothesis revisited. J. Psychiatr. Res. 28, 239-265.

Knickmeyer, R. C., Gouttard, S., Kang, C., Evans, D., Wilber, K., Smith, J. K., Hamer, R. M., Lin, W., Gerig, G., and
Gilmore, J. H. (2008). A structural MRI study of human brain development from birth to 2 years. J. Neurosci. 28, 12176-12182.

Kolluri, N., Sun, Z., Sampson, A. R., and Lewis, D. A. (2005). Lamina-specific reductions in dendritic spine density in the prefrontal cortex of subjects with schizophrenia. Am. J. Psychiatry 162, 1200-1202.

Koo, M. S., Levitt, J. J., Salisbury, D. F. Nakamura, M., Shenton, M. E., and McCarley, R. W. (2008). A crosssectional and longitudinal magnetic resonance imaging study of cingulate gyrus gray matter volume abnormalities in first-episode schizophrenia and first-episode affective psychosis. Arch. Gen. Psychiatry 65, 746-760.

Kostovic, I., and Rakic, P. (1980). Cytology and time of origin of interstitial neurons in the white matter in infant and adult human and monkey telencephalon. J. Neurocytol. 9, 219-242.

Kreczmanski, P., Heinsen, H., Mantua, V., Woltersdorf, F., Masson, T., Ulfig, N., Schmidt-Kastner, R., Korr, H., Steinbusch, H. W., Hof, P. R., and Schmitz, C. (2007). Volume, neuron density and total neuron number in five subcortical regions in schizophrenia. Brain 130, 678-692.

Kreczmanski, P., Schmidt-Kastner, R. Heinsen, H., Steinbusch, H. W. Hof, P. R., and Schmitz, C. (2005). Stereological studies of capillary length density in the frontal cortex of schizophrenics. Acta Neuropathol. 109, 510-518.

Kubicki, M., McCarley, R., Westin, C. F., Park, H. J., Maier, S., Kikinis, R., Jolesz, F.A., and Shenton, M. E. (2007). A review of diffusion tensor imaging studies in schizophrenia. J. Psychiatr. Res. 41, 15-30.

Kubicki, M., Westin, C. F., Nestor, P. G., Wible, C. G., Frumin, M., Maier, S. E., Kikinis, R.,Jolesz, F.A.,McCarley, R. W., and Shenton, M. E. (2003). Cingulate fasciculus integrity disruption in schizophrenia: a magnetic resonance diffusion tensor imaging study. Biol. Psychiatry 54, 1171-1180.

Kulynych, J. J., Luevano, L. F., Jones, D. W. and Weinberger, D. R. (1997). Cortical abnormality in schizophrenia: an in vivo application of the gyrification index. Biol. Psychiatry 41, 995-999.

Kumra, S., Ashtari, M., Cervellione, K. L., Henderson, I., Kester, H., Roofeh, D., Wu, J., Clarke, T., Thaden, E., Kane, J. M., Rhinewine, J., Lencz, T. Diamond, A., Ardekani, B. A., and Szeszko, P. R. (2005). White matter abnormalities in early-onset schizophrenia: a voxel-based diffusion tensor imaging study. J. Am. Acad. Child Adolesc. Psychiatry 44, 934-941.
Kunishio, K., and Haber, S. N. (1994). Primate cingulostriatal projection limbic striatal versus sensorimotor striatal input. J. Comp. Neurol. 350, 337-356.

Lappe-Siefke, C., Goebbels, S., Gravel, M., Nicksch, E., Lee, J., Braun, P. E. Griffiths, I. R., and Nave, K. A. (2003). Disruption of Cnpl uncouples oligodendroglial functions in axonal support and myelination. Nat. Genet. 33, 366-374.

Larocque, D., and Richard, S. (2005). QUAKING KH domain proteins as regulators of glial cell fate and myelination. RNA Biol. 2, 37-40.

Lauriat, T. L., Shiue, L., Haroutunian, V. Verbitsky, M., Ares, M. Jr, Ospina, L. and McInnes, L. A. (2008). Developmental expression profile of quaking, a candidate gene for schizophrenia, and its target genes in human prefrontal cortex and hippocampus shows regional specificity. J. Neurosci. Res. 86, 785-796.

Lenroot, R. K., and Giedd, J. N. (2006) Brain development in children and adolescents: insights from anatomical magnetic resonance imaging. Neurosci. Biobehav. Rev. 30, 718-729.

Levinson, D. F., Mahtani, M. M. Nancarrow, D.J.,Brown,D.M.,Kruglyak, L., Kirby, A., Hayward, N. K., Crowe, R. R., Andreasen, N. C., Black, D. W. Silverman, J. M., Endicott, J., Sharpe, L. Mohs, R. C., Siever, L. J., Walters, M K., Lennon, D. P., Jones, H. L., Nertney, D A., Daly, M. J., Gladis, M., and Mowry, B. J. (1998). Genome scan of schizophrenia. Am. J. Psychiatry 155, 741-750.

Lewis, D. A., and Levitt, P. (2002) Schizophrenia as a disorder of neurodevelopment. Annu. Rev. Neurosci. $25,409-432$.

Li, C., Tropak, M. B., Gerlai, R., Clapoff, S. Abramow-Newerly, W., Trapp, B., Peterson, A., and Roder, J. (1994). Myelination in the absence of myelinassociated glycoprotein. Nature 369 747-750.

Lim, K. O., Hedehus, M., Moseley, M. de Crespigny, A., Sullivan, E. V., and Pfefferbaum,A. (1999). Compromised white matter tract integrity in schizophrenia inferred from diffusion tensor imaging. Arch. Gen. Psychiatry 56, 367-374.

Lindholm, E., Ekholm, B., Shaw, S., Jalonen, P., Johansson, G., Pettersson, U., Sherrington, R., Adolfsson, R., and Jazin, E. (2001). A schizophrenia-susceptibility locus at $6 \mathrm{q} 25$, in one of the world's largest reported pedigrees. Am. J. Hum. Genet. 69, 96-105.

Liu, X., Qin, W., He, G., Yang, Y., Chen, Q., Zhou, J., Li, D., Gu, N., Xu, Y., Feng, G.
Sang, H., Hao, X., Zhang, K., Wang, S., and He, L. (2005). A family-based association study of the MOG gene with schizophrenia in the Chinese population. Schizophr. Res. 73, 275-280.

Loers, G., Aboul-Enein, F., Bartsch, U., Lassmann, H., and Schachner, M. (2004). Comparison of myelin, axon, lipid, and immunopathology in the central nervous system of differentially myelin-compromised mutant mice: a morphological and biochemical study. Mol. Cell. Neurosci. 27, 175-189.

Lyon, G., Fattal-Valevski, A., and Kolodny, E. H.(2006).Leukodystrophies: clinical and genetic aspects. Top. Magn. Reson. Imaging 17, 219-242.

Mata,I.,Perez-Iglesias, R.,Roiz-Santianez, R., Tordesillas-Gutierrez, D., GonzalezMandly,A., Vazquez-Barquero, J.L., and Crespo-Facorro, B. (2009). A neuregulin 1 variant is associated with increased lateral ventricle volume in patients with first-episode schizophrenia. Biol. Psychiatry 65, 535-540.

McCullumsmith, R. E., Gupta, D., Beneyto, M., Kreger, E., Haroutunian, V., Davis, K. L., and Meador-Woodruff, J. H. (2007). Expression of transcripts for myelination-related genes in the anterior cingulate cortex in schizophrenia. Schizophr. Res. 90, 15-27.

McInnes, L. A., and Lauriat, T. L. (2006). RNA metabolism and dysmyelination in schizophrenia. Neurosci. Biobehav. Rev. 30, 551-561.

Miller, J. H., McKinstry, R. C., Philip, J. V., Mukherjee, P., and Neil, J. J. (2003). Diffusion-tensor MR imaging of normal brain maturation: a guide to structural development and myelination. AJR Am. J. Roentgenol. 180, 851-859.

Mirsky, A. F., Rosvold, H. E., and Pribram, K. H. (1957). Effects of cingulectomy on social behavior in monkeys. J. Neurophysiol. 20, 588-601.

Montag, D., Giese, K. P., Bartsch, U., Martini, R., Lang, Y., Bluthmann, H., Karthigasan, J., Kirschner, D. A. Wintergerst, E. S., Nave, K. A., Zielasek, J., Toyka, K. V., Lipp, H. P., and Schachner, M. (1994). Mice deficient for the myelin-associated glycoprotein show subtle abnormalities in myelin. Neuron 13, 229-246.

Mukherjee, P., and McKinstry, R. C. (2006). Diffusion tensor imaging and tractography of human brain development. Neuroimaging Clin. N. Am. 16, 19-43, vii.

Mukherjee, P., Miller, J. H., Shimony, J. S., Conturo, T. E., Lee, B. C., Almli, C. R., and McKinstry, R. C. (2001). Normal brain maturation during childhood: developmental trends characterized with diffusion-tensor MR imaging. Radiology 221, 349-358 
Mukherjee, P., Miller, J. H., Shimony, J. S., Philip, J. V., Nehra, D., Snyder, A. Z., Conturo, T. E., Neil, J. J., and McKinstry, R. C. (2002). Diffusiontensor MR imaging of gray and white matter development during normal human brain maturation. AJNR Am. J. Neuroradiol. 23, 1445-1456.

Munafo, M. R., Thiselton, D. L., Clark, T. G., and Flint, J. (2006). Association of the NRG1 gene and schizophrenia: a meta-analysis. Mol. Psychiatry 11, 539-546.

Narr, K. L., Bilder, R. M., Toga, A. W., Woods, R. P., Rex, D. E., Szeszko, P. R., Robinson, D., Sevy, S., GunduzBruce, H., Wang, Y. P., DeLuca, H., and Thompson, P. M. (2005). Mapping cortical thickness and gray matter concentration in first episode schizophrenia. Cereb. Cortex $15,708-719$.

Neafsey, E. J. (1990). Prefrontal cortical control of the autonomic nervous system: anatomical and physiological observations. Prog. Brain Res. 85, 147-165; discussion 165-146.

Nesvag, R., Lawyer, G., Varnas, K., Fjell, A. M., Walhovd, K. B., Frigessi, A., Jonsson, E. G., and Agartz, I. (2008). Regional thinning of the cerebral cortex in schizophrenia: effects of diagnosis, age and antipsychotic medication. Schizophr. Res. 98, 16-28.

Nikulina, E. M., Skrinskaya, J. A., Avgustinovich, D. F., and Popova, N. K. (1995). Dopaminergic brain system in the quaking mutant mouse. Pharmacol. Biochem. Behav. 50, 333-337.

Norton, N., Moskvina, V., Morris, D. W., Bray, N. J.,Zammit, S., Williams, N.M., Williams, H.J., Preece, A. C., Dwyer, S., Wilkinson, J.C., Spurlock, G., Kirov, G., Buckland, P., Waddington, J. L., Gill, M., Corvin, A. P., Owen, M. J., and O’Donovan, M. C. (2006). Evidence that interaction between neuregulin 1 and its receptor erbB4 increases susceptibility to schizophrenia. Am. J. Med. Genet. B Neuropsychiatr. Genet. 141B, 96-101.

Novak, G., Kim, D., Seeman, P., and Tallerico, T. (2002). Schizophrenia and Nogo: elevated mRNA in cortex, and high prevalence of a homozygous CAA insert. Brain Res. Mol. Brain Res. 107, 183-189.

O'Kusky, J., and Colonnier, M. (1982). Postnatal changes in the number of astrocytes, oligodendrocytes, and microglia in the visual cortex (area 17) of the macaque monkey: a stereological analysis in normal and monocularly deprived animals. J. Comp. Neurol. 210, 307-315.

Okugawa, G., Tamagaki, C., and Agartz, I. (2007). Frontal and temporal volume size of grey and white matter in patients with schizophrenia: an MRI parcellation study. Eur. Arch. Psychiatry Clin. Neurosci. 257, 304-307.

Ongür, D., Ferry, A. T., and Price, J. L. (2003). Architectonic subdivision of the human orbital and medial prefrontal cortex. J. Comp. Neurol. 460, 425-449.

Palomero-Gallagher, N., Mohlberg, H., Zilles, K., and Vogt, B. (2008). Cytology and receptor architecture of human anterior cingulate cortex. J. Comp. Neurol. 508, 906-926.

Pan, B., Fromholt, S. E., Hess, E. J., Crawford, T. O., Griffin, J. W., Sheikh, K. A., and Schnaar, R. L. (2005). Myelin-associated glycoprotein and complementary axonal ligands, gangliosides, mediate axon stability in the CNS and PNS: neuropathology and behavioral deficits in single- and double-null mice. Exp. Neurol. 195, 208-217.

Paus, T. (2005). Mapping brain maturation and cognitive development during adolescence. Trends Cogn. Sci. 9, 60-68.

Paus, T., Collins, D. L., Evans, A. C., Leonard, G., Pike, B., and Zijdenbos, A. (2001). Maturation of white matter in the human brain: a review of magnetic resonance studies. Brain Res. Bull. 54, 255-266.

Paus, T., Keshavan, M., and Giedd, J. N. (2008). Why do many psychiatric disorders emerge during adolescence? Nat. Rev. Neurosci. 9, 947-957.

Peirce, T. R., Bray, N. J., Williams, N. M., Norton, N., Moskvina, V., Preece, A., Haroutunian, V., Buxbaum, J. D., Owen, M. J., and O'Donovan, M. C. (2006). Convergent evidence for 2',3'cyclic nucleotide 3 '-phosphodiesterase as a possible susceptibility gene for schizophrenia. Arch. Gen. Psychiatry 63, 18-24.

Pettegrew, J. W., Keshavan, M. S., Panchalingam, K., Strychor, S., Kaplan, D. B., Tretta, M. G., and Allen, M. (1991). Alterations in brain high-energy phosphate and membrane phospholipid metabolism in first-episode, drug-naive schizophrenics. A pilot study of the dorsal prefrontal cortex by in vivo phosphorus 31 nuclear magnetic resonance spectroscopy. Arch. Gen. Psychiatry $48,563-568$.

Pfefferbaum, A., Mathalon, D. H., Sullivan, E.V., Rawles, J.M.,Zipursky, R. B., and Lim, K. O. (1994). A quantitative magnetic resonance imaging study of changes in brain morphology from infancy to late adulthood. Arch. Neurol. 51, 874-887.

Qin, W., Gao, J., Xing, Q., Yang, J., Qian, X., Li, X., Guo, Z., Chen, H., Wang, L., Huang, X., Gu, N., Feng, G., and
He, L. (2005). A family-based association study of PLP1 and schizophrenia. Neurosci. Lett. 375, 207-210.

Quarles, R.H. (2009). A hypothesis about the relationship of myelin-associated glycoprotein's function in myelinated axons to its capacity to inhibit neurite outgrowth. Neurochem. Res. 34, 79-86.

Radley, J. J., Rocher, A. B., Rodriguez, A., Ehlenberger, D. B., Dammann, M., McEwen, B. S., Morrison, J. H. Wearne, S. L., and Hof, P. R. (2008). Repeated stress alters dendritic spine morphology in the rat medial prefrontal cortex. J. Comp. Neurol. 507, 1141-1150.

Rajkowska, G., Selemon, L. D., and Goldman-Rakic, P. S. (1998). Neuronal and glial somal size in the prefrontal cortex: a postmortem morphometric study of schizophrenia and Huntington disease. Arch. Gen. Psychiatry 55, 215-224.

Rapoport, J. L., Addington, A. M., Frangou, S., and Psych, M. R. (2005) The neurodevelopmental model of schizophrenia: update 2005. Mol. Psychiatry 10, 434-449.

Rioux, L., Nissanov, J., Lauber, K. Bilker, W. B., and Arnold, S. E. (2003). Distribution of microtubule-associated protein MAP2-immunoreactive interstitial neurons in the parahippocampal white matter in subjects with schizophrenia. Am. J. Psychiatry 160, 149-155.

Ross, S. E., Greenberg, M. E., and Stiles, C. D. (2003). Basic helix-loophelix factors in cortical development. Neuron 39, 13-25.

Roy, K., Murtie, J. C., El-Khodor, B. F., Edgar, N., Sardi, S. P., Hooks, B. M. Benoit-Marand, M., Chen, C., Moore, H., O'Donnell, P., Brunner, D. and Corfas, G. (2007). Loss of erbB signaling in oligodendrocytes alters myelin and dopaminergic function, a potential mechanism for neuropsychiatric disorders. Proc. Natl. Acad. Sci. USA 104, 8131-8136.

Rudebeck, P. H., Bannerman, D. M., and Rushworth, M. F. (2008). The contribution of distinct subregions of the ventromedial frontal cortex to emotion, social behavior, and decision making. Cogn. Affect. Behav. Neurosci. 8, 485-497.

Rushworth, M. F., Behrens, T. E., Rudebeck, P. H., and Walton, M. E. (2007a). Contrasting roles for cingulate and orbitofrontal cortex in decisions and social behaviour. Trends Cogn. Sci. 11, 168-176.

Rushworth, M. F., Buckley, M. J., Behrens, T. E., Walton, M. E., and Bannerman,D.M. (2007b). Functional organization of the medial frontal cortex. Curr. Opin. Neurobiol. 17, 220-227.

Sauvageot, C. M., and Stiles, C. D. (2002). Molecular mechanisms controlling cortical gliogenesis. Curr. Opin. Neurobiol. 12, 244-249.

Savonenko, A. V., Melnikova, T., Laird, F. M.,Stewart, K.A., Price, D. L. and Wong, P. C. (2008). Alteration of BACE1-dependent NRG1/ErbB4 signaling and schizophrenia-like phenotypes in BACE1-null mice. Proc. Natl. Acad. Sci. USA 105, 5585-5590.

Schmahmann, J. D., and Pandya, D. N. (2007). Cerebral white matter - historical evolution of facts and notions concerning the organization of the fiber pathways of the brain. J. Hist. Neurosci. 16, 237-267.

Schmahmann, J. D., Pandya, D. N., Wang, R., Dai, G., D'Arceuil, H. E., de Crespigny, A. J., and Wedeen, V. J. (2007). Association fibre pathways of the brain: parallel observations from diffusion spectrum imaging and autoradiography. Brain 130, 630-653.

Schmahmann, J. D., Smith, E. E., Eichler, F. S., and Filley, C. M. (2008). Cerebral white matter: neuroanatomy, clinical neurology, and neurobehavioral correlates. Ann. N. Y. Acad. Sci. 1142, 266-309.

Schmued, L., and Slikker, W. Jr (1999). Black-gold: a simple, high-resolution histochemical label for normal and pathological myelin in brain tissue sections. Brain Res. 837, 289-297.

Segal, D. (2008). Cingulum bundle pathophysiology in schizophrenia. $\mathrm{PhD}$ Thesis, Department of Neuroscience, Mount Sinai School of Medicine, New York.

Segal, D., Haznedar, M. M., Newmark, R. E., Torosjan, Y., Friedman, J., Schneiderman, J. S., Chu, K.-W., Hazlett, E. A., Mitropoulou, V., Tang, C. Y., Hof, P. R. and Buchsbaum, M. S. (2007a). Diffusion tensor anisotropy in the cingulate gyrus in schizophrenia. San Diego, SFN (abstract 805.23).

Segal,D., Koschnick,J.R.,Slegers, L. H., and Hof, P. R. (2007b). Oligodendrocyte pathophysiology: a new view of schizophrenia. Int.J. Neuropsychopharmacol. 10, 503-511.

Segal,D.,Schmitz, C., and Hof,P.R. (2009). Spatial distribution and density of oligodendrocytes in the cingulum bundle are unaltered in schizophrenia. Acta Neuropathol. 117, 385-394.

Selemon, L. D., Begovic, A., GoldmanRakic, P. S., and Castner, S. A. (2007). Amphetamine sensitization alters dendriticmorphology in prefrontal cortical pyramidal neurons in the non-human 
primate. Neuropsychopharmacology 32, 919-931.

Selemon, L. D., and Goldman-Rakic, P. S. (1999). The reduced neuropil hypothesis: a circuit based model of schizophrenia. Biol. Psychiatry $45,17-25$.

Selemon, L. D., Rajkowska, G., and Goldman-Rakic, P. S. (1995). Abnormally high neuronal density in the schizophrenic cortex. A morphometric analysis of prefrontal area 9 and occipital area 17. Arch. Gen. Psychiatry $52,805-820$.

Selemon, L. D., Rajkowska, G., and Goldman-Rakic, P. S. (1998). Elevated neuronal density in prefrontal area 46 in brains from schizophrenic patients: application of a three-dimensional, stereologic counting method. J. Comp. Neurol. 392, 402-412.

Shergill, S. S., Kanaan, R. A., Chitnis, X. A., O'Daly, O., Jones, D. K., Frangou, S., Williams, S. C., Howard, R. J., Barker, G. J., Murray, R. M., and McGuire, P. (2007). A diffusion tensor imaging study of fasciculi in schizophrenia. Am. J. Psychiatry 164, 467-473.

Sidman, R. L., Dickie, M. M., and Appel, S. H. (1964). Mutant mice (quaking and jimpy) with deficient myelination in the central nervous system. Science 144, 309-311.

Sinibaldi, L., De Luca, A., Bellacchio, E., Conti, E., Pasini, A., Paloscia, C., Spalletta, G., Caltagirone, C., Pizzuti, A., and Dallapiccola, B. (2004). Mutations of the Nogo-66 receptor (RTN4R) gene in schizophrenia. Hum. Mutat. 24, 534-535.

Smith, W. K. (1945). The functional significance of the rostral cingular cortex as revealed by its responses to electrical excitation. J. Neurophysiol. 8, 241-255.

Sokolov, B. P. (2007). Oligodendroglial abnormalities in schizophrenia, mood disorders and substance abuse. Comorbidity, shared traits, or molecular phenocopies? Int. J. Neuropsychopharmacol. 10, 547-555.

Sowell, E. R., Peterson, B. S., Thompson, P. M., Welcome, S. E., Henkenius, A. L., and Toga, A. W. (2003). Mapping cortical change across the human life span. Nat. Neurosci. 6, 309-315.

Sowell, E. R., Thompson, P. M., and Toga, A. W. (2004). Mapping changes in the human cortex throughout the span of life. Neuroscientist 10, 372-392.

Sporn, A. L., Greenstein, D. K., Gogtay, N., Jeffries, N.O.,Lenane, M.,Gochman, P., Clasen, L. S., Blumenthal, J., Giedd, J. N., and Rapoport, J. L. (2003). Progressive brain volume loss during adolescence in childhoodonset schizophrenia. Am. J. Psychiatry 160, 2181-2189.

Stark, A. K., Uylings, H. B. M., SanzArigita, E., and Pakkenberg, B. (2004). Glial cell loss in the anterior cingulate cortex, a subregion of the prefrontal cortex, in subjects with schizophrenia. Am. J. Psychiatry 161, 882-888.

Stefansson, H., Sarginson, J., Kong, A., Yates, P., Steinthorsdottir, V., Gudfinnsson, E., Gunnarsdottir, S., Walker, N., Petursson, H., Crombie, C., Ingason, A., Gulcher, J. R., Stefansson, K., and St Clair, D. (2003). Association of neuregulin 1 with schizophrenia confirmed in a Scottish population. Am. J. Hum. Genet. 72, 83-87.

Stefansson, H., Sigurdsson, E., Steinthorsdottir, V., Bjornsdottir, S., Sigmundsson, T., Ghosh, S., Brynjolfsson, J., Gunnarsdottir, S., Ivarsson, O., Chou, T. T., Hjaltason, O., Birgisdottir, B., Jonsson, H., Gudnadottir, V. G., Gudmundsdottir, E., Bjornsson, A., Ingvarsson, B., Ingason, A., Sigfusson, S., Hardardottir, H., Harvey, R. P., Lai, D., Zhou, M., Brunner, D., Mutel, V., Gonzalo, A., Lemke, G., Sainz, J., Johannesson, G., Andresson, T., Gudbjartsson, D., Manolescu, A., Frigge, M. L., Gurney, M.E., Kong, A., Gulcher, J. R., Petursson, H., and Stefansson, K. (2002). Neuregulin 1 and susceptibility to schizophrenia. Am. J. Hum. Genet. 71, 877-892.

Sugai, T., Kawamura, M., Iritani, S., Araki, K., Makifuchi, T., Imai, C., Nakamura, R., Kakita,A., Takahashi, H., and Nawa, H. (2004). Prefrontal abnormality of schizophrenia revealed by DNA microarray: impact on glial and neurotrophic gene expression. Ann. N. Y. Acad. Sci. 1025, 84-91.

Sun, Z., Wang, F., Cui, L., Breeze, J., Du, X., Wang, X., Cong, Z., Zhang, H., Li, B., Hong, N., and Zhang, D. (2003). Abnormal anterior cingulum in patients with schizophrenia: a diffusion tensor imaging study. Neuroreport 14, 1833-1836.

Sun, Z.Y., Wei, J., Xie, L., Shen, Y., Liu, S.Z., Ju, G. Z., Shi, J. P., Yu, Y. Q., Zhang, X., $\mathrm{Xu}, \mathrm{Q}$., and Hemmings, G. P. (2004). The CLDN5 locus may be involved in the vulnerability to schizophrenia. Eur. Psychiatry 19, 354-357.

Sussman, C. R., Vartanian, T., and Miller, R. H. (2005). The ErbB4 neuregulin receptor mediates suppression of oligodendrocyte maturation. J. Neurosci. 25, 5757-5762.

Sweet, R. A., Henteleff, R. A., Zhang, W., Sampson,A.R., and Lewis, D.A. (2009). Reduced dendritic spine density in auditory cortex of subjects with schizophrenia. Neuropsychopharmacology 34, 374-389.

Tamminga, C. A., Thaker, G. K., Buchanan, R., Kirkpatrick, B., Alphs, L. D., Chase, T. N., and Carpenter, W. T. (1992). Limbic system abnormalities identified in schizophrenia using positron emission tomography with fluorodeoxyglucose and neocortical alterations with deficit syndrome. Arch. Gen. Psychiatry 49, 522-530.

Tang, F., Qu, M., Wang, L., Ruan, Y., Lu, T., Zhang, H., Liu, Z., Yue, W., and Zhang, D. (2007). Case-control association study of the $2^{\prime}, 3^{\prime}$-cyclic nucleotide $3^{\prime}$-phosphodiesterase (CNP) gene and schizophrenia in the Han Chinese population. Neurosci. Lett. 416, 113-116.

Thompson, P.M., Sowell, E. R., Gogtay, N., Giedd,J.N.,Vidal,C.N.,Hayashi, K. M., Leow, A., Nicolson, R., Rapoport, J. L., and Toga, A. W. (2005). Structural MRI and brain development. Int. Rev. Neurobiol. 67, 285-323.

Thompson, P. M., Vidal, C., Giedd, J. N., Gochman, P., Blumenthal, J., Nicolson, R., Toga, A. W., Rapoport, J. L. (2001). Mapping adolescent brain change reveals dynamic wave of accelerated gray matter loss in very early-onset schizophrenia. Proc. Natl. Acad. Sci. U. S. A. 98, 11650-11655.

Tkachev, D., Mimmack, M. L., Ryan, M. M., Wayland, M., Freeman, T., Jones, P. B., Starkey, M., Webster, M. J., Yolken, R. H., and Bahn, S. (2003). Oligodendrocyte dysfunction in schizophrenia and bipolar disorder. Lancet 362, 798-805.

Toga, A. W., Thompson, P. M., and Sowell, E. R. (2006). Mapping brain maturation. Trends Neurosci. 29, 148-159.

Uranova, N., Orlovskaya, D., Vikhreva, O., Zimina, I., Kolomeets, N., Vostrikov, V., and Rachmanova, V. (2001). Electron microscopy of oligodendroglia in severe mental illness. Brain Res. Bull. $55,597-610$.

Uranova, N. A., Vostrikov, V. M., Orlovskaya, D. D., and Rachmanova, V. I. (2004). Oligodendroglial density in the prefrontal cortex in schizophrenia and mood disorders: a study from the Stanley neuropathology consortium. Schizophr. Res. 67, 269-275.

Usui, H., Takahashi, N., Saito, S., Ishihara, R., Aoyama, N., Ikeda, M., Suzuki, T., Kitajima, T., Yamanouchi, Y., Kinoshita, Y., Yoshida, K., Iwata, N., Inada, T., and Ozaki, N. (2006). The 2', $3^{\prime}$-cyclic nucleotide $3^{\prime}$-phosphodiesterase and oligodendrocyte lineage transcription factor 2 genes do not appear to be associated with schizophrenia in the Japanese population. Schizophr. Res. 88, 245-250.

Van Hoesen, G. W., Morecraft, R. J., and Vogt, B. A. (1993). Connections of the monkey cingulate cortex. In Neurobiology of Cingulate Cortex and Limbic Thalamus, B. A. Vogt and M. Gabriel, eds (Boston, Birkhauser), pp. 249-284.

Vogt, B. A., Nimchinsky, E. A., Vogt, L. J., and Hof,P.R. (1995). Human cingulate cortex: surface features, flat maps, and cytoarchitecture. J. Comp. Neurol.359, 490-506.

Vogt, B. A., and Pandya, D. N. (1987). Cingulate cortex of the rhesus monkey: II. Cortical afferents. J. Comp. Neurol. 262, 271-289.

Vogt, B.A.,Pandya, D.N., and Rosene, D. L. (1987). Cingulate cortex of the rhesus monkey: I. Cytoarchitecture and thalamic afferents. J. Comp. Neurol. 262, 256-270.

Voineskos, A. N., de Luca, V., Bulgin, N. L., van Adrichem, Q., Shaikh, S. Lang, D. J., Honer, W. G., and Kennedy, J. L. (2008). A family-based association study of the myelin-associated glycoprotein and $2^{\prime}, 3^{\prime}$-cyclic nucleotide $3^{\prime}$-phosphodiesterase genes with schizophrenia. Psychiatr. Genet. $18,143-146$.

Volpe, J. J. (2000). Overview: normal and abnormal human brain development. Ment. Retard. Dev. Disabil. Res. Rev. 6,1-5.

Walterfang, M., Wood, S. J., Velakoulis, D., Copolov, D., and Pantelis, C. (2005). Diseases of white matter and schizophrenia-like psychosis. Aust. N. Z. J. Psychiatry 39, 746-756.

Walterfang, M., Wood, S. J., Velakoulis, D., and Pantelis, C. (2006). Neuropathological, neurogenetic and neuroimaging evidence for white matter pathology in schizophrenia. Neurosci. Biobehav. Rev. 30, 918-948.

Wang, F., Sun, Z., Cui, L., Du, X., Wang, X., Zhang, H., Cong, Z., Hong, N., and Zhang, D. (2004). Anterior cingulum abnormalities in male patients with schizophrenia determined through diffusion tensor imaging. Am. J. Psychiatry 161, 573-575.

Wang, L., Hosakere, M., Trein, J. C., Miller, A., Ratnanather, J. T., Barch, D. M., Thompson, P. A., Qiu, A., Gado, M. H., Miller, M.I., and Csernansky,J.G. (2007).Abnormalities of cingulate gyrus neuroanatomy in schizophrenia. Schizophr. Res. 93, 66-78.

Weinberger, D. R. (1986). The pathogenesis of schizophrenia: a neurodevelopmental theory. In The Neurology of Schizophrenia, H. A. W. Nasrallah 
and D.R.Weinberger, eds (Amsterdam, Elsevier), pp. 397-406.

Weinberger, D. R. (1987). Implications of normal brain development for the pathogenesis of schizophrenia. Arch. Gen. Psychiatry 44, 660-669.

Weiss, M. D., Hammer, J., and Quarles, R.H. (2000). Oligodendrocytes in aging mice lacking myelin-associated glycoprotein are dystrophic but not apoptotic. $J$. Neurosci. Res. 62, 772-780.

Weiss, M. D., Luciano, C. A., and Quarles, R. H. (2001). Nerve conduction abnormalities in aging mice deficient for myelin-associated glycoprotein. Muscle Nerve 24, 1380-1387.

White, T., Cullen, K., Rohrer, L. M., Karatekin, C., Luciana, M., Schmidt, M., Hongwanishkul, D., Kumra, S., Charles Schulz, S., and Lim, K. O. (2008). Limbic structures and networks in children and adolescents with schizophrenia. Schizophr. Bull. 34, 18-29.

Williams, N. M., Preece, A., Spurlock, G., Norton, N., Williams, H. J., Zammit, S., O'Donovan, M. C., and Owen, M. J. (2003). Support for genetic variation in neuregulin 1 and susceptibility to schizophrenia. Mol. Psychiatry 8, 485-487.

Woo, T. U., and Crowell, A. L. (2005). Targeting synapses and myelin in the prevention of schizophrenia. Schizophr. Res. 73, 193-207.

Xi, Z. R., Qin, W., Yang, Y. F., He, G., Gao, S. H., Ren, M. S., Peng, Y. W., Zhang, Z., and He, L. (2004). Transmission disequilibrium analysis of the GSN gene in a cohort of family trios with schizophrenia. Neurosci. Lett. 372, 200-203.

Xiong, L., Rouleau, G. A., Delisi, L. E., St-Onge, J., Najafee, R., Riviere, J. B., Benkelfat, C., Tabbane, K., Fathalli, F., Danics, Z., Labelle, A., Lal, S., and
Joober, R. (2005). CAA insertion polymorphism in the $3^{\prime}$ UTR of Nogo gene on 2p14 is not associated with schizophrenia. Brain Res. Mol. Brain Res. 133, 153-156.

Xu, H., Yang, H. J., Zhang, Y., Clough, R. Browning, R., and Li, X. M. (2009). Behavioral and neurobiological changes in C57BL/6 mice exposed to cuprizone. Behav. Neurosci. 123, 418-429.

Yakovlev, P., and Lecours, A. (1967) The myelogenetic cycles of regional maturation of the brain. In Regional Development of the Brain in Early Life, A. Minkowski, ed. (Oxford, Blackwell), pp. 3-70.

Zhang, Y., Xu, H., Jiang, W., Xiao, L., Yan, B., He, J., Wang, Y., Bi, X., Li, X., Kong, J., and Li, X. M. (2008). Quetiapine alleviates the cuprizoneinduced white matter pathology in the brain of C57BL/6 mouse. Schizophr. Res. 106, 182-191.
Conflict of Interest Statement: The authors declare that the research was conducted in the absence of any commercial or financial relationships that could be construed as a potential conflict of interest.

Received: 28 April 2009; paper pending published: 03 June 2009; accepted: 16 June 2009; published online: 02 July 2009.

Citation: Höistad M, Segal D, Takahashi $N$, Sakurai T, Buxbaum JD and Hof PR (2009) Linking white and grey matter in schizophrenia: oligodendrocyte and neuron pathology in the prefrontal cortex. Front. Neuroanat. (2009) 3:9. doi: 10.3389/neuro.05.009.2009

Copyright (@) 2009Höistad, Segal, Takahashi, Sakurai, Buxbaum and Hof. This is an open-access article subject to an exclusive license agreement between the authors and the Frontiers Research Foundation, which permits unrestricted use, distribution, and reproduction in any medium, provided the original authors and source are credited. 